\title{
The Solid-Phase Synthesis of the Inorganic Non-Stoichiometric Compounds-Fibrous Fluorosilicates
}

\author{
Naira B. Yeritsyan and Lida A. Khachatryan \\ Name Institute of General and Inorganic Chemistry, National Academy of Science \\ Republic of Armenia
}

\section{Introduction}

The synthesis of inorganic non-stoichiometric compounds such as thermostable fibrous fluorosilicates of amphibole group shaped in form of fibrous-acicular crystals represents one of the perspective directions in the modern materials science. The importance of fibrous amphiboles, including synthetic fibrous fluorosilicates (FFS) derives from multifunctionality and specificity of their properties. They are elastic, flexible, and resistant to aggressive media, have high mechanic strength, low electric and heat conductance, heat and fire resistance, express an ability to absorb certain gases and liquids, etc. By present, fibrous amphiboles and their synthetic counterparts in pure state or composed with other substances (pitch, rubber, cement, ceramics, carbon fluoride) are widely used in various fields of modern industry and technique. The main consumers of fibrous silicates and fibrous-based composites are chemical and electro-technical industries, the manufacturing of fillers for electrolytic chambers and for acid dampers, the production of electrical wires, plastic and rubber for special purposes, paints, clays, varnishes, lubricants in the motor-car, aircraft, ship-building, and rocket plants. In atomic power engineering these compounds are used as structuring and insulting materials (Khachatryan, 1969; Hawkins, 1971; Grigor'eva et al., 1975; Li, 1992, Tareev, 2002-2011).

The existing evidence suggests that these thermostable inorganic polymers are conventionally obtained under hydrothermal conditions in the temperature range of 300$900^{\circ} \mathrm{C}$ and water vapour pressure of 20-300 MPa as well as under pyrogenic conditions by melt crystallization at $1300-1450^{\circ} \mathrm{C}$, and by solid-phase synthesis (Khachatryan, 1969; Grigor'eva et al., 1975; Goncharov and Kovalenko, 1973). The latter method, when compared with others, offers the chance to synthesize fibrous asbestos-like fluoramphiboles at relatively lower temperature (in the range of $900-1100^{\circ} \mathrm{C}$ ) and under atmospheric pressure. In this process the chemical reactants and natural pure minerals, both of stoichiometric composition, are used as the raw materials. Nevertheless, the intensification and reduction in energy costs of processes are required to further optimize the conditions of synthesis. This can be achieved by widening the raw material base and determining new complex feedstocks of non-stoichiometric composition, which should be inexpensive and readily available. Following this general trend, we have proposed to use the mining rocks. 
This approach, together with its practical significance, would allow the covering of a number of theoretical questions in the fields of inorganic chemistry, physical chemistry, and silicate crystallochemistry, solid-state physics, ecology, materials science and other adjacent disciplines.

For the first time, the artificial analogues of fibrous amphiboles from mining rocks under hydrothermal (with end products hydroxyl- and hydroxyl-fluoramphiboles) and pyrogenic (from the melt and by solid-phase synthesis, the end product: fluoramphibolesfluorsilicates) conditions were obtained (Khachatryan, 1969; Yeritsyan and Khachatryan, 2003, 2005).

In this chapter we provide a comparative analysis of the existing evidence with regard to the method of solid-phase synthesis of fibrous fluorosilicates from different blends based either on chemical reactants, pure minerals or mining rocks of magnesium-silicate composition, namely serpentinite, dunite, peridotite and pyroxenite. We summarize the results of our experiments aimed to unveil the impact of different compositions of initial blends and thermal-temporal conditions of synthesis on the yield of FFS as well as on the morphology and size of their crystals. To better understand the mechanisms of phase and chemical modifications in the course of FFS-synthesis the feedstock mining rocks are thoroughly characterized using the methods of microscopic, thermal, X-ray at room and high temperatures, and chemical assays. Finally, the chemical composition, structural and optical features of yield FFSs are followed together with their chemical, thermal, and adsorptive properties.

The results of the systemic investigations presented in the chapter highlight some aspects of phase-formation inside the complex multicomponent fluorosilicate systems and discuss the principles of fibrous fluorosilicate morphogenesis in the course of solid-phase synthesis from mining rocks.

\section{Chemical composition and structure of amphibole}

Amphiboles refer to the class of silicates with chain-ribbon structure. They crystallize in monoclinic and rhombic crystal systems. The long-prismatic crystals of these compounds possess an absolute cleavage.

Amphiboles are characterized by complex chemical composition with a general cristallochemical formula $\mathrm{AX}_{2} \mathrm{Y}_{3}\left[\mathrm{Z}_{8} \mathrm{O}_{22}\right](\mathrm{OH}, \mathrm{F}, \mathrm{Cl})_{2}$, where the cations $\mathrm{Na}^{+}, \mathrm{K}^{+}, \mathrm{Ca}^{2+}$ or some vacancies are placed in the position $\mathrm{A} ; \mathrm{Li}^{+}, \mathrm{Na}^{+}, \mathrm{Ca}^{2+}, \mathrm{Mg}^{2+}$ in the position $\mathrm{X} ; \mathrm{Mg}^{2+}$, $\mathrm{Fe}^{2+}, \mathrm{Fe}^{3+}, \mathrm{Mn}^{2+}, \mathrm{Al}^{3+}, \mathrm{Cr}^{3+}$ in the position $\mathrm{Y}$; and $\mathrm{Si}^{4+}, \mathrm{B}^{3+}, \mathrm{Al}^{3+}, \mathrm{Fe}^{3+}, \mathrm{Ti}^{4+}, \mathrm{Ga}^{4+}$ in the position $\mathrm{Z}$. The structure of amphiboles includes double chains of silico-oxygenic tetrahedrons $\left[\mathrm{Si}_{4} \mathrm{O}_{11}\right]_{\infty}^{6-}$, between which the cations $\mathrm{Y}$ are located in the octahedral positions M1, M2, M3 (Fig.1). The position M4 on the edges of octahedral cationcontaining chains is occupied by cations $X$. The surplus (more than two) cations $X$ are located in the channels between the chains (the position A). The anionic polymer chains, which are extended along the crystallographic axis $c$ in the amphiboles, represent the structural prerequisite for the formation of fibrous-acicular crystals. Nevertheless, it is important to underline that fibrous crystals are not the only, and not even the most widespread products of crystallization under either natural or experimental conditions. 

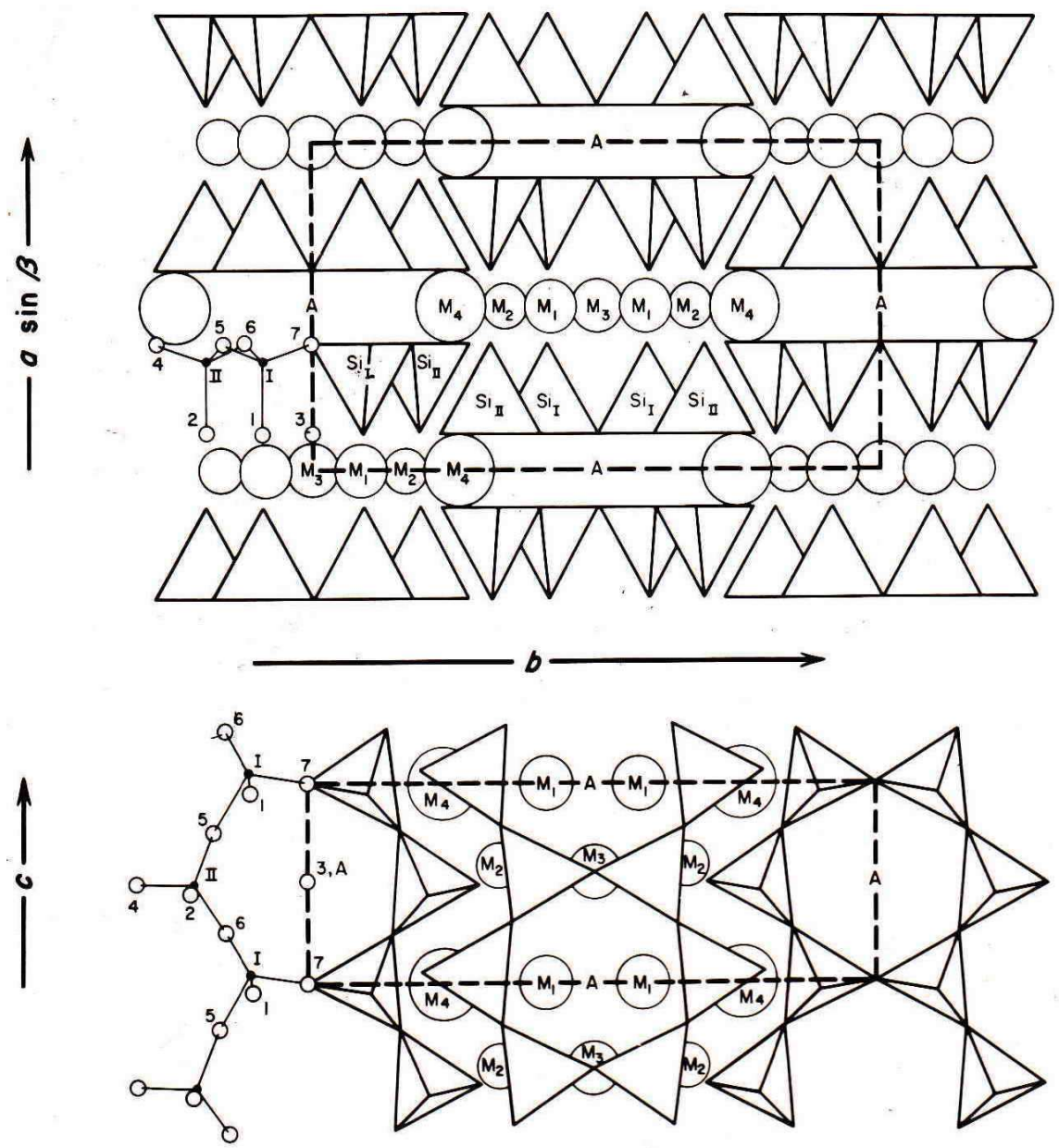

Fig. 1. The structure of monoclinic amphibole in the plane (001) and (100) after Ernst (1968).

The structure of these compounds can undergo a wide range of isomorphic substitutions. The latter determines the formation of different impurities in the composition of the natural amphiboles and provides the variability of their properties, the features, which restrict the use of FFS for a number of important objectives. Therefore, the yield of synthetic fibrous amphiboles with goal-defined stable characteristics greatly attracts the attention of many researchers in the modern materials science.

The presence of vacancies and the potential capability for iso- and heterovalent substitutions in the different structural positions of these non-stoichiometric compounds enables the purposeful development of their properties, and thereby, the synthesis of new inorganic polymers with better physicochemical and technical properties. The yield of thermostable fibrous fluorosilicates, for instance, is achieved by the replacement of hydroxyl group $(\mathrm{OH})^{-}$by $\mathrm{F}^{-}$. 
The high isomorphic capacity of FFS provides a perspective to synthesize novel fibrous amphiboles from affordable and inexpensive feedstocks of non-stoichiometric composition, e.g. from mining rocks and waste products.

\section{Solid-phase synthesis of fluorosilicates}

The yield of fibrous (asbestos-like) fluorosilicates by solid-phase synthesis was described first in the early 1930s by german scientists Scheumann (1932) and Lüdke $(1933,1943)$. This approach was further developed by the works after Eitel (1952), Espig (1962), Gibbs et al. (1962), and Saito et al. (1965). Since 1963 this topic became a subject of great interest and detailed investigation performed by Fedoseev A. and colleagues (1963-1975). These researchers used chemical reactants (oxides, fluorides, carbonates) and natural pure minerals (talc, chlorite, rodusite, phlogopite, olivine, serpentine, enstatite) as initial substrates. The use of these compounds allowed the yield of fluoramphibole at $900-1100^{\circ} \mathrm{C}$ under atmospheric pressure. The synthesis was carried out in tightly closed ceramic, graphitic, and platinic bowls or airtight capsules from carbon steel in furnaces with aerial, neutral or reconstructive media. After prolonged isothermic exposure required for the solidphase reactions to proceed, the temperature was lowered. Although the chemical modifications occurred mainly due to interactions between the particles of initial batches, the concomitant gaseous and liquid phases appeared to alter drastically the rate of the process as well as the composition and shape of the yield products.

Irrespective to the nature of initial components the yield products of solid phase synthesis were represented by dense poriferous cake, which consisted of radial aggregates and heterooriented needles or fibres of fluoramphibole having $0.5-1.0 \mathrm{~mm}$ length and $0.1-10 \mu \mathrm{m}$ thickness (Grigor' eva et al., 1975). Depending on the raw stuff used, they contained 25-95\% of fluoramphiboles. Fluorides, crystobalite, tridymite, forsterite, humite minerals, pyroxens, mica, glass, etc, were mentioned as conventional impurities. Fluoramphibole often formed 'brush'-like monomineral structures on the surface of yield products (Espig, 1962; Chigareva et al., 1966; Fedoseev et al., 1966; Grigor' eva et al., 1975). The fibres in the surface 'brush' had a length around 5-25 mm and thickness $1-50 \mu \mathrm{m}$ and constituted 1-5\% of product weight.

Altogether, the accumulated evidence suggested that the method of solid-phase synthesis enables the yield of fibrous fluoramphiboles of different chemical compositions and with a variety of physicochemical properties (Fedoseev et al., 1966; Chigareva, 1967; Grigor'eva et al., 1975). For instance, two such compounds, NaMg-fluorrichterite and NaMgfluorarfvedsonite do not concede to their natural analogues richterite and arfvedsonite by their mechanical strength, chemical resistance, and elasticity, but express higher thermostability. This occurs due to the energy of breaking the chemical bond for $\mathrm{Mg}-\mathrm{OH}$ $(56 \pm 5 \mathrm{kcal} / \mathrm{mol})$ in natural minerals being significantly lower than that the one for the $\mathrm{Mg}-\mathrm{F}$ bond $(120 \pm 20 \mathrm{kcal} / \mathrm{mol})$ in their synthetic fluor-containing counterparts. Given the restriction in the natural sources of richterite and arfvedsonite, the synthesis of their artificial counterparts is of huge interest, since they can be used as reinforcing fillers in the development of new commercial materials.

In the next section we describe the process of solid-phase synthesis of NaMg-fluorrichterite and NaMg-fluorarfvedsonite from raw stuff of stoichiometric (chemical reactants and minerals) and non-stoichiometric (mining rocks) compositions. The physical-chemical 
parameters of the synthesis and properties of the yield product will be compared with respect to the different initial batches.

\subsection{Solid-phase synthesis of fluorosilicates from raw material of stoichiometric composition}

The initial batches used to synthesize fibrous fluorosilicates of non-stoichiometric composition were first described to consist of stoichiometric chemical reactants and pure minerals (Fedoseev et al., 1966, 1970; Chigareva, 1967; Goncharov and Kovalenko, 1973; Grigor'eva et al., 1975; Tresvyatskiy, 1982). These batches corresponded to the compositions of NaMgfluorrichterite and $\mathrm{NaMg}$-fluorarfvedsonite with variable excess of fluorine, and contained air-dry (dried and burnt in advance) reactants such as $\mathrm{SiO}_{2}, \mathrm{MgO}, \mathrm{MgF}_{2}, \mathrm{NaCl}, \mathrm{Na}_{2} \mathrm{CO}_{3}, \mathrm{Fe}_{2} \mathrm{O}_{3}$, etc, and pure minerals olivin, chlorite, serpentine, phlogopite, enstatite, talc, roducite, etc.

The formation of magnesio-fluorrichterite $\left(\mathrm{Na}_{2} \mathrm{Mg}_{6}\left[\mathrm{Si}_{8} \mathrm{O}_{22}\right] \mathrm{F}_{2}\right)$ most productively proceeded in the $\mathrm{SiO}_{2}, \mathrm{MgO}, \mathrm{Na}_{2} \mathrm{CO}_{3}$-containing initial batches supplemented with the mixture of $\mathrm{NaF}$ and $\mathrm{MgF}_{2}$. Fluoramphiboles, including $\mathrm{NaMg}$-fluorrichterite, were obtained by solid-phase synthesis in the system of $\mathrm{NaF}-\mathrm{MgF}_{2}-\mathrm{MgO}-\mathrm{MeO}-\mathrm{SiO}_{2}\left(\mathrm{Me}=\mathrm{Ni}^{2+}, \mathrm{Co}^{2+}, \mathrm{Cr}^{3+}\right)$ within the temperature range $600-1150^{\circ} \mathrm{C}$. Fibrous fluoramphiboles of NaMg-fluorarfvedsonite $\left(\mathrm{Na}_{2.5} \mathrm{Mg}_{4.5} \mathrm{Fe}^{3+}\left[\mathrm{Si}_{8} \mathrm{O}_{22}\right] \mathrm{F}_{2}, \mathrm{Na}_{3} \mathrm{Mg}_{4} \mathrm{Fe}^{3+}\left[\mathrm{Si}_{8} \mathrm{O}_{22}\right] \mathrm{F}_{2}\right)$ compositions were yield at $800-1050^{\circ} \mathrm{C}$.

The synthesis was reported to take place in open and closed systems represented by not tightly closed platinic bowls and by sealed off quartz capsules respectively. Within the open system the amorphous silica turned to tridimite and the formation of forsterite $\left(\mathrm{Mg}_{2} \mathrm{SiO}_{4}\right)$ occurred at $700^{\circ} \mathrm{C}$. Fluornorbergite $\left(\mathrm{Mg}_{2} \mathrm{SiO}_{4} \cdot \mathrm{MgF}_{2}\right)$, which was initially formed at the edges of forsterite grains crystallized at $800^{\circ} \mathrm{C}$. Fluorides were shaped as caked granules $\left(\mathrm{n}_{\mathrm{m}}=1.406\right)$ within the temperature range of $650-810^{\circ} \mathrm{C}$. Neiborite $\left(\mathrm{NaMgF}_{3}\right)$ and the local foci of eutectic crystallization of fluoride $\left(\mathrm{NaF}+\mathrm{NaMgF}_{3}\right)$ emerged along with these granules upon heating above $800^{\circ} \mathrm{C}$. Magnesio-fluorrichterite was yield at $900^{\circ} \mathrm{C}$. The characteristics, sequence, and thermal ranges of mentioned phases were not much different when using the closed system. However, the concentration fields of crystallization for all fluorine-containing compounds were shifted toward lower content of $\mathrm{MgF}_{2}$.

In powder-like crystalline reagents mixtures, the transformation proceeded due to direct interactions between the particles of initial substances with the contribution of liquid and gaseous phases. The latter substantially enhanced the rate of the processes. Several studies were undertaken to establish the conditions enabling high rates of solid-phase reactions in fluoramphibole formation. For instance, attributing importance to the impact of gaseous phase, Scheumann (1932) and Lüdke (1933) used the pneumatolytic approach to synthesize fluoramphiboles in the stream of water vapour. Further, gas-forming supplements were introduced into the initial batches by other researchers (Espig, 1962; Saito et al., 1965; Fedoseev et al., 1970; Goncharov et al., 1973). In some works the synthesis was initiated in the reducing media (Goncharov et al., 1973) or in the presence of mineralizing fluxes (Espig, 1962, Fedoseev et al., 1966, 1970).

The experimental evidence gained in this field allowed an assumption that the formation of NaMg-fluorrichterite from oxides and fluorides in the course of solid-phase synthesis using the open system approach resulted from the reactions (1)-(4). The formation of forsterite in the first stage of these reactions was considered to be thermodynamically preferential, as it 
occurred in the magnesium-silicate systems different by their component ratio (Budnikov and Ginstling, 1971).

$$
\begin{aligned}
& \mathrm{NaF}+\mathrm{MgF}_{2} \rightarrow \mathrm{NaMgF}_{3} \\
& \text { neiborite } \\
& 2 \mathrm{MgO}+\mathrm{SiO}_{2} \rightarrow \mathrm{Mg}_{2} \mathrm{SiO}_{4} \\
& \text { forsterite } \\
& \mathrm{Mg}_{2} \mathrm{SiO}_{4}+\mathrm{MgF}_{2} \rightarrow \mathrm{Mg}_{2} \mathrm{SiO}_{4} \cdot \mathrm{MgF}_{2} \\
& \text { fluornorbergite } \\
& 9 \mathrm{SiO}_{2}+\mathrm{MgF}_{2}+\mathrm{Mg}_{2} \mathrm{SiO}_{4} \cdot \mathrm{MgF}_{2}+\mathrm{NaMgF}_{3} \rightarrow \mathrm{Na}_{2} \mathrm{Mg}_{6}\left[\mathrm{Si}_{8} \mathrm{O}_{22}\right] \mathrm{F}_{2}+2 \mathrm{SiF}_{4} \uparrow \\
& \mathrm{NaMg} \text { - fluorrichterite }
\end{aligned}
$$

These interactions might also develop when natural minerals from the group of orthosilicates (olivine) or magnesium hydrosilicates (chlorite and serpentine) were introduced to the initial batches. These minerals were reported to decay upon heating with the yield of forsterite (Grigor' eva et al., 1975). The formation of fluoramphibole from dehydrated phlogopite proceeded through the generation of amorphous cluster of rough composition $3 \mathrm{MgO} \cdot 2 \mathrm{SiO}_{2}$, in accord to the reaction (5). An inclusion of natural enstatite or the hydrosilicates (talc and roducite), the dehydration process of which usually ends up with the yield of pyroxens, was thought to influence the course of the reaction (6):

$$
\begin{aligned}
& 4\left(3 \mathrm{MgO} \cdot 2 \mathrm{SiO}_{2}\right)+19 \mathrm{SiO}_{2}+6 \mathrm{MgF}_{2}+6 \mathrm{NaF} \rightarrow 3 \mathrm{Na}_{2} \mathrm{Mg}_{6}\left[\mathrm{Si}_{8} \mathrm{O}_{22}\right] \mathrm{F}_{2}+3 \mathrm{SiF}_{4} \uparrow \\
& \mathrm{NaMg}-\text { fluorrichterite } \\
& 4 \mathrm{MgSiO}_{3}+5 \mathrm{SiO}_{2}+2 \mathrm{MgF}_{2}+2 \mathrm{NaF} \rightarrow \underset{\mathrm{NaMg}}{\rightarrow} \mathrm{Mg}_{6}\left[\mathrm{Si}_{8} \mathrm{O}_{22}\right] \mathrm{F}_{2}+\mathrm{SiF}_{4} \uparrow \\
& \mathrm{NaMg}-\text { fluorrichterite }
\end{aligned}
$$

Main parameters of synthesis, i. e. the nature of initial reagents, the content of fluorine in the initial batch, thermal conditions, cooling rate and duration of the experiments, highly influence the completeness of interactions, the rate of the process and the morphology of fluoramphibole crystals. As it was demonstrated in studies of the kinetics of $\mathrm{NaMg}$-fluorrichterite formation in the isothermic regimen at $1000^{\circ} \mathrm{C}$, the initial stage of the process was limited by chemical reaction, while its further development was restricted by diffusion. The yield of fluoramphibole synthesized from chemical reactants was of $75-95 \%$, whereas this percentage was markedly lower in the end product obtained from pure minerals (around 30-50\%).

The maximal yield of magnesio-fluorrichterite $(85-95 \%)$ was registered at $950-1050^{\circ} \mathrm{C}$. The fibres of this silicate were shaped at $900-950^{\circ} \mathrm{C}$. Above $1000^{\circ} \mathrm{C}$ a prismatic appearance of crystals was reported (Grigor' eva et al., 1975). Monomineral clusters, which contain fluoramphibole fibers and needles having 5-30 $\mathrm{mm}$ in length, were crystallized on the surface of yield product (Fig. 2). This took place in the initial batch under the condition of the fluorine excess, which constituted $5-10 \%$ from the stoichiometric composition of synthesized fluoramphibole. An additional requirement for the cluster formation was the thermal gradient of around $10^{\circ} \mathrm{C} / \mathrm{cm}$ ascertained along the whole height of bowl. 
Then fluorides characteristics specified the composition of local foci of eutectic melt within the reaction mixture and determine the temperature of their generation. Such foci greatly intensified the process of $\mathrm{NaMg}$-fluorrichterite formation. The supplementation of the initial batches with fusible salts, e.g. $\mathrm{NaCl}, \mathrm{Na}_{2} \mathrm{CO}_{3}, \mathrm{Na}_{2} \mathrm{SO}_{3}$, etc, promoted the appearance of local clusters of melt at $680-740^{\circ} \mathrm{C}$. The use of mineralizing compounds in the solid-phase synthesis under certain conditions enabled higher yield of fluoramphibole and purposeful adjustment of crystal habits from fibrous to short-prismatic.

Thus, the process of solid-phase synthesis of fluoramphibole from either chemical reactants or pure natural silicates and hydrosilicates, i.e. compounds of stoichiometric compositions, was represented by multistep physicochemical interactions conventional for the formation of non-stoichiometric inorganic compounds (Rabenau, 1970). The mechanisms of this process were estimated by the properties of new phases emerged during the decomposition of hydrosilicates.

Fibrous fluoramphiboles of NaMg-fluorarfvedsonite composition were obtained by the solid-phase synthesis from the initial batches containing chemical reactants $\mathrm{SiO}_{2}, \mathrm{MgO}$, $\mathrm{Fe}_{2} \mathrm{O}_{3}, \mathrm{Na}_{2} \mathrm{CO}_{3}$, and $\mathrm{NaCl}$ treated at $800-1000^{\circ} \mathrm{C}$ as well as from the blend consisting of these reactants additionally supplemented with pure mineral roducite at $800-1050^{\circ} \mathrm{C}$ (Chigareva et al., 1966, 1971). The content of fluoramphiboles of $\mathrm{Na}_{2.5} \mathrm{Mg}_{4.5} \mathrm{Fe}^{3+}\left[\mathrm{Si}_{8} \mathrm{O}_{22}\right] \mathrm{F}_{2}$ and $\mathrm{Na}_{3} \mathrm{Mg}_{4} \mathrm{Fe}^{3+}\left[\mathrm{Si}_{8} \mathrm{O}_{22}\right] \mathrm{F}_{2}$ compositions in the final products constituted around $95 \%$ and $60 \%$ respectively. The crystals of fluoramphiboles were fibrous or fine-acicular, having $0.05-4 \mathrm{~mm}$ in length and 1-5 $\mu \mathrm{m}$ in thickness.
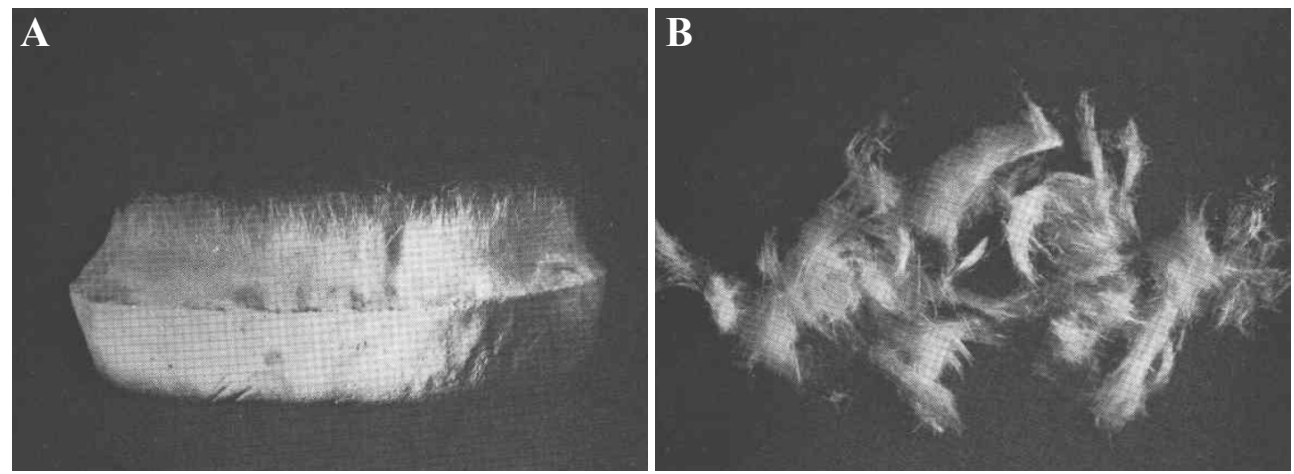

Fig. 2. Synthetic fibrous fluoramphibole: general view of the synthesis product $(A, 0.8 \mathrm{x})$ and fibrous crystals $(B, 0.7 x)$ (Fedoseev et al., 1970).

The crystallochemical formula of obtained NaMg-fluorrichterite corresponded to $\mathrm{Na}_{2.12} \mathrm{Mg}_{5.85} \mathrm{Fe}^{3+}{ }_{0.01}\left[\mathrm{Si}_{8} \mathrm{O}_{21.88}\right] \mathrm{F}_{2.09}$ (to compare: the theoretical composition of this silicate was $\mathrm{Na}_{2} \mathrm{Mg}_{6} \mathrm{Si}_{8} \mathrm{O}_{22} \mathrm{~F}_{2}$ ). For NaMg-fluorarfvedsonite it is expressed as $\mathrm{Na}_{2.58} \mathrm{Ca}_{0.10} \mathrm{Mg}_{4.49} \mathrm{Fe}^{3+}{ }_{0.97}\left[\left(\mathrm{Si}_{7.84} \mathrm{Al}_{0.03}\right) \mathrm{O}_{22}\right]\left(\mathrm{O}_{0.10} \mathrm{~F}_{1.70} \mathrm{Cl}_{0.20}\right)$ vs. theoretical composition $\mathrm{Na}_{2.5} \mathrm{Mg}_{4.5} \mathrm{Fe}^{3+} \mathrm{Si}_{8} \mathrm{O}_{22} \mathrm{~F}_{2}$, and $\mathrm{Na}_{3} \mathrm{Ca}_{0.16} \mathrm{Mg}_{3.89} \mathrm{Fe}^{3+}{ }_{1.25}\left[\left(\mathrm{Si}_{7.73} \mathrm{Al}_{0.05}\right) \mathrm{O}_{21.04}\right]\left(\mathrm{F}_{1.70} \mathrm{Cl}_{0.36}\right) \quad$ vs. theoretical formula $\mathrm{Na}_{3} \mathrm{Mg}_{4} \mathrm{Fe}^{3+} \mathrm{Si}_{8} \mathrm{O}_{22} \mathrm{~F}_{2}$. The findings of crystallooptical and X-ray assays, which describe the refractive index and parameters of crystal lattice, as well as physicalchemical properties of synthesized fluoramphiboles are summarized in the tables 1 and 7 , according to Grigor'eva et al. (1975). 


\begin{tabular}{|l|c|c|c|c|c|c|c|c|}
\hline \multirow{2}{*}{$\begin{array}{l}\text { Fluoramphibole } \\
\text { composition }\end{array}$} & \multicolumn{4}{|c|}{ Parameters of crystal lattice } & \multicolumn{4}{c|}{ Optical constants } \\
\cline { 2 - 9 } & $\mathrm{a}, \mathrm{nm}$ & $\mathrm{b}, \mathrm{nm}$ & $\mathrm{c}, \mathrm{nm}$ & $\beta$ & $\mathrm{Ng}$ & $\mathrm{Np}$ & $\mathrm{Ng}-\mathrm{Np}$ & $\mathrm{cNg}$ \\
\hline NaMg-fluorrichterite & 0.967 & 1.792 & 0,527 & $103^{\circ} 00^{\prime}$ & 1.596 & 1.577 & 0.019 & $12^{\circ}$ \\
\hline $\begin{array}{l}\text { NaMg- } \\
\text { fluorarfvedsonite }\end{array}$ & 0.974 & 1.787 & 0,528 & $103^{\circ} 36^{\prime}$ & 1.630 & 1.618 & 0.012 & $20^{\circ}$ \\
\hline
\end{tabular}

Table 1. Parameters of crystal-lattice and optical characteristics of NaMg-fluorrichterite and NaMg-fluorarfvedsonite.

To further develop technological procedures of NaMg-fluorrichterite synthesis in term of the estimating the optimal composition of initial blends, thermal and temporal parameters of the solid-state reactions enabling the maximal yield of the fibrous amphibole with minimal content of impurities, and testing the reproducibility of cycles, Goncharov and Kovalenko (1973) used burnt and dried in advance chemical reactants (oxides, fluorides, chlorides, etc). The synthesis was carried out in the airtight bowls from low-carbon steel in the furnace with hydrogenous protective atmosphere, i.e. in the reducing media. The supplementation of flux sodium chloride $(\mathrm{NaCl})$ in quantity of $25 \%$ from the weight of the initial blend changed the habitus of fluoramphibole crystals from acicular and prismatic to fibrous. The basic parameters of the synthesis were the following: the temperature of the synthesis $-1050-1100^{\circ} \mathrm{C}$, retention time at this temperature $-48 \mathrm{~h}$, and a composition of the blend $-2.5 \mathrm{NaF} \cdot 0.5 \mathrm{MgF}_{2} \cdot 5.5 \mathrm{MgO} \cdot 8 \mathrm{SiO}_{2}+25 \% \mathrm{NaCl}$. The fluoramphibole fibres were of $0.05-0.15 \mathrm{~mm}$ lenghth and of $5-10 \mu \mathrm{m}$ in thickness. The chemical analysis revealed, that the synthesized compound had the chemical formula $\left(\mathrm{Na}_{1.89} \mathrm{~K}_{0.02}\right)_{1.91} \mathrm{Mg}_{5.9}\left[\mathrm{Si}_{8} \mathrm{O}_{22.14}\right] \mathrm{F}_{1.86}$.

The described approaches of solid-phase synthesis, i.e. from chemical reactants and pure minerals, reveal a number of qualities restricting their use as conventional methods to obtain fibrous fluroamphiboles of $\mathrm{NaMg}$-fluorrichterite and $\mathrm{NaMg}$-fluorarfvedsonite composition. They consume expensive feedstocks (chemical reactants and pure minerals), which require additional treatment of burning and drying. This treatment by heating the substances upon $300-800^{\circ} \mathrm{C}$, along with high temperature of the main process (above 950 $1050^{\circ} \mathrm{C}$ ) sets demands for a complex and labour-consuming technology. Therefore, we investigated the process of solid-phase synthesis of fibrous fluoramphiboles from affordable and inexpensive complex raw materials - mining rocks, which mainly contain the minerals of magnesium-silicate composition.

\subsection{Solid-phase synthesis of fluoramphiboles from raw material of non-stoichiometric composition - Mining rocks}

\subsubsection{Properties of the mining rocks}

We used as feedstocks the ultra-alkaline mining rocks from local mines: serpentinite (S), serpentinite calcinated at $700^{\circ} \mathrm{C}$ to constant weigt $\left(S_{\text {calcin }}\right)$, dunite $(\mathrm{D})$, peridotite $(\mathrm{P})$, and pyroxenite $(\mathrm{Px})$. The mining rocks were utilized in form of fine grinded powder with the granule size less than $50 \mu \mathrm{m}$. The rocks were studied by chemical (Table 2), microscopic (Table 3), X-ray diffraction at room and high temperatures (Fig. 7A), and differential thermal (derivatograph OD-103, Fig. 6, curve 1) assays. From the analysis of chemical and mineralogical compositions it became evident that dunite, peridotite and pyroxenite were substantially serpentinized and represented the classical samples of ultra-alkaline rocks. 
They belonged to the non-stoichiometric compounds consisted of several minerals and were used here to donate the oxides $\mathrm{MgO}, \mathrm{SiO}_{2}, \mathrm{Fe}_{2} \mathrm{O}_{3}$ into the composition of initial blends.

\begin{tabular}{|c|c|c|c|c|}
\hline \multirow{2}{*}{ Oxydes } & \multicolumn{4}{|c|}{ Rocks, wt \% } \\
\cline { 2 - 5 } & Serpentinite & Peridotite & Dunite & Pyroxenite \\
\hline $\mathrm{SiO}_{2}$ & 40.05 & 35.30 & 38.05 & 40.97 \\
\hline $\mathrm{Al}_{2} \mathrm{O}_{3}$ & 2.50 & 0.38 & 0.43 & 1.68 \\
\hline $\mathrm{Fe}_{2} \mathrm{O}_{3}$ & 4.12 & 5.54 & 4.66 & 8.15 \\
\hline $\mathrm{FeO}$ & 2.77 & 1.87 & 3.22 & - \\
\hline $\mathrm{TiO}_{2}$ & Traces & not found & not found & traces \\
\hline $\mathrm{CaO}$ & 3.19 & 0.95 & 1.01 & 6.30 \\
\hline $\mathrm{MgO}$ & 35.70 & 37.59 & 38.84 & 32.60 \\
\hline $\mathrm{MnO}$ & - & 0.09 & 0.10 & - \\
\hline $\mathrm{SO}_{3}$ & Traces & 0.16 & 0.16 & traces \\
\hline $\mathrm{CO}_{2}$ & - & 1.42 & 0.96 & - \\
\hline $\mathrm{Na}_{2} \mathrm{O}$ & 0.07 & 0.03 & 0.16 & 0.09 \\
\hline $\mathrm{K}_{2} \mathrm{O}$ & 0.08 & 0,03 & 0.03 & 0.06 \\
\hline $\mathrm{Cr}_{2} \mathrm{O}_{3}$ & 0.60 & 0.31 & 0.33 & 0.25 \\
\hline $\mathrm{Loss}$ & 11.10 & 14.44 & 11.16 & 9.40 \\
\hline Moisture of the rock & 0.19 & 2.26 & 1.23 & 0.5 \\
\hline$\Sigma$ & 100.35 & 100.33 & 100.29 & 99.25 \\
\hline
\end{tabular}

Table 2. Chemical composition of initial rocks.

\begin{tabular}{|l|l|c|}
\hline Rock & \multicolumn{1}{|c|}{ Minerals } & $\begin{array}{c}\text { Content, wt } \\
\%\end{array}$ \\
\hline Serpentinite & Serpentine (antigorite) & $\sim 80$ \\
& Monoclinic pyroxenes & $\sim 10-15$ \\
Magnetite & $\sim 5-7$ \\
\hline Peridotite & Olivine (serpentinous, from which $~ 10 \%$ invariable olivine) & $\sim 70$ \\
& Rombic pyroxene(enstatite) & $\sim 15-20$ \\
& Monoclinic pyroxenes (diopside, diallag) & $5-10$ \\
& Magnetite (secondary), chromospinelide & $3-5$ \\
\hline Dunite & Sarbonates & $1.5-2.5$ \\
\hline Perpentines (chrysotile, antigorite) & $\sim 40-45$ \\
& Olivine & $\sim 40-45$ \\
& Pyroxenes & $\sim 5$ \\
& Magnetite and chromospinelide & $\sim 3-8$ \\
& Carbonates & $\sim 2$ \\
\hline & Serpentine (described as chrysotile, antigorite, serpofite, from & $\sim 40$ \\
& which $~ 5 \%$ chlorite) & $5-10$ \\
& Enstatite & $40-50$ \\
& Monoclinic pyroxenes (diopcide, diallag) & $5-7$ \\
\hline
\end{tabular}

Table 3. Mineralogical composition of initial rocks. 
The composition of initial blends was calculated from the theoretical formula of the $\mathrm{NaMg}$ fluorarfvedsonite $\left(\mathrm{Na}_{3} \mathrm{Mg}_{4} \mathrm{Fe}^{3+}\left[\mathrm{Si}_{8} \mathrm{O}_{22}\right] \mathrm{F}_{2 \mathrm{n}}\right)$, where $\mathrm{n}$ represented an excess digits of fluorine atoms. The excessive content of fluorine in the blend varied within the range of 4.54-27.24 wt $\%$, that constituted $n=1,2,3,4,5,6$ atoms per formula unit of the amphibole. Initial blends together with the mining rocks contained supplementing stoichiometric chemical reactants $\mathrm{Na}_{2} \mathrm{SiF}_{6}, \mathrm{NaF}, \mathrm{NaCl}$, and $\mathrm{Na}_{2} \mathrm{CO}_{3}$, which were used without additional treatment (burning, drying, or powdering).

We examined seven reaction blends of the following compositions: S- and $\mathrm{S}_{\text {calcin }}-\mathrm{NaF}$ (I, II), S- and $\mathrm{S}_{\text {calcin }}-\mathrm{Na}_{2} \mathrm{SiF}_{6}$ (III, IV), D - $\mathrm{Na}_{2} \mathrm{SiF}_{6}(\mathrm{~V}), \mathrm{P}-\mathrm{Na}_{2} \mathrm{SiF}_{6}(\mathrm{VI})$, and Px - $\mathrm{Na}_{2} \mathrm{SiF}_{6}$ (VII). Sodium carbonate and sodium chloride were introduced as fluxes $(10-30 \mathrm{wt} \%)$. The amount of supplemented $\mathrm{SiO}_{2}$ was equal to 3-10 wt\%. The fibrous fluorosilicates were synthesized in fluorine-steady vessels in the electrical resistance furnaces.

The phase composition in the products of rock treatment and the synthesized compounds were examined by the crystal optical, differential thermal (DTA, OD-103), X-ray diffraction with use of powder and single-crystal methods (DRON-2 and URS-70 diffractometers, $\mathrm{CuK}_{\alpha}$-radiation, Ni-filter), and electronnomicroscopic (Tesla BS-242) assays.

\subsubsection{Results and discussion}

Initial mixtures were heated upon $500-1000^{\circ} \mathrm{C}$ during $1-60 \mathrm{~h}$. The synthesized products were mainly represented by an array of tangled fibrous texture with surface monomineral 'brush' of fluorosilicate fibers (see Fig. 10)

The phase composition of synthesized samples, the percentage of FFS yield (i.e. the rate of rock transformation and fluorosilicate content), the mechanisms and rate of the processes, the morphology and size of FFS crystals were greatly influenced by the parameters of synthesis (the properties and the quantity of mining rocks, fluorine-introducing components $\mathrm{NaF}$ and $\mathrm{Na}_{2} \mathrm{SiF}_{6}$, and fluxes $\mathrm{NaCl}$ and $\mathrm{Na}_{2} \mathrm{CO}_{3}$; thermal-temporal conditions of the process, etc.).

Fluorine content was manipulated by supplementation of a fluorine-introducing agent, e.g. $\mathrm{Na}_{2} \mathrm{SiF}_{6}$ in the blends III, IV, V, VI, VII, and $\mathrm{NaF}$ in the blends I and II. The amount of fluorine varied from 4.5 to $27 \mathrm{wt} \%$, i. e. with an excess in regard to the theoretical composition of synthesized amphibole. The experiments carried out at $900-920^{\circ} \mathrm{C}$ and exposure of $48 \mathrm{~h}$ revealed that when using $\mathrm{NaF}$ the rate of $\mathrm{S}$ and $\mathrm{S}_{\text {calcin }}$ modification into fluorosilicate was $25-30 \%$ and $65-70 \%$ respectively. In these series we failed to obtain monosized and long fibres on the surface of the product. Distinct fibres in the 'brush' were around 1-3 $\mathrm{mm}$ in length. The process of rock treatment proceeded more actively in the reaction blends supplemented with fluorine through $\mathrm{Na}_{2} \mathrm{SiF}_{6}$. The optimal amount of fluorine in the initial blends to obtain the product with high content of fine-fibrous crystals and well developed 'brush' on the surface was found to constitute $7.00-13.50 \mathrm{wt} \%$ (3-6 fluorine atoms per formula unit of the amphibole, Fig. 3).

In case of low ( $\leq 2$ fluorine atoms per formula unit) and high ( $\geq 10$ fluorine atoms per formula unit) fluorine content the amphibole was crystallized in form of thick and prismatic crystals. 

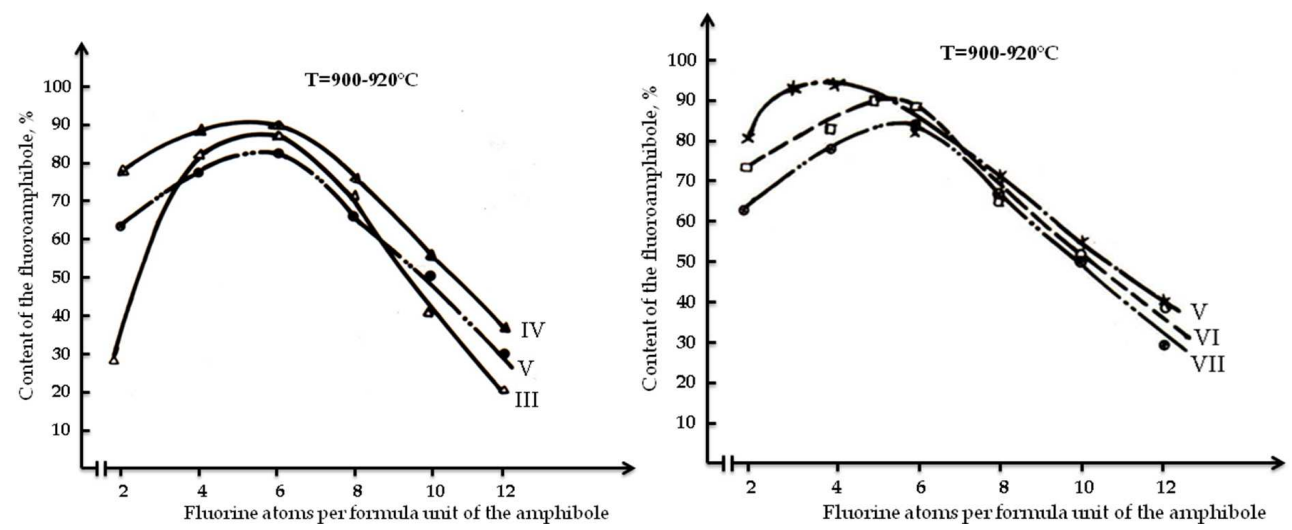

Fig. 3. The dependence of the yield of fluorosilicates on the content of fluorine in the initial blends containing: III -serpentinite, IV - calcinated serpentinite, V - dunite, VI - peridotite, and VII - pyroxenite.

The properties and the amount of fluorides determined the composition and the temperature of formation for the gaseous phase and for the local eutectic melt in the reaction blends. In its turn, the latter factors intensified the process of magnesium-arfvedsonite formation. The supplementation of the initial blends with fusible salts such as $\mathrm{NaCl}$ and $\mathrm{Na}_{2} \mathrm{CO}_{3}$ promoted the generation of local foci of the melt, i.e. the formation of the reactioncapable liquid phase, at relatively low temperature $\left(\leq 450^{\circ} \mathrm{C}\right)$. This extended the thermal capacity of the fluoramphibole formation toward rather low temperatures. The introduction of $\mathrm{Na}_{2} \mathrm{CO}_{3}$ resulted in strong caking of the treatment product, which contained $30-40 \%$ of fluorosilicate in form of short prismatic crystals. The introduction of $\mathrm{NaCl}$ into the blends led to the yield of asbestos-like FFS, which constituted in average $75-92 \%$ in case of $10-30$ $w t \%$ of $\mathrm{NaCl}$ supplement. An increase in the content of fluxes from 30 to $70 \mathrm{wt} \%$ had no effect on rock transformation rate, but substantially influenced the morphology of fluorosilicate crystals by decreasing the amount of fibrous crystals in favour to the particles with acicular-prismatic habits.

Thus, the use of mineralizing compounds in solid-phase synthesis enabled the yield of the product with high concentration of fluorosilicate as well as the purposeful adjustment of crystal habits from fibrous toward short prismatic one.

Further, to clarify how a dispersion of raw components influence the process of synthesis we studied the impact of differently sized granules of monomineral rock serpentinite and of multimineral dunite. The size of granules varied from 50 to $600 \mu \mathrm{m}$. Variation in dispersivity of both rocks altered the yield of the fluorosilicate and the morphology of the crystals. Nevertheless, the effect was stronger expressed in case of serpentinite (Fig. 4).

The use of serpentinite granules of $400-600 \mu \mathrm{m}$ resulted in the prevalence of dissociated fibrous aggregate of fluoramphibole in the end products. Acicular and prismatic crystals were formed when testing granule size $400-90 \mu \mathrm{m}$. A decrease in size less than $50 \mu \mathrm{m}$ led to the formation of detached fine fibres and needles. 


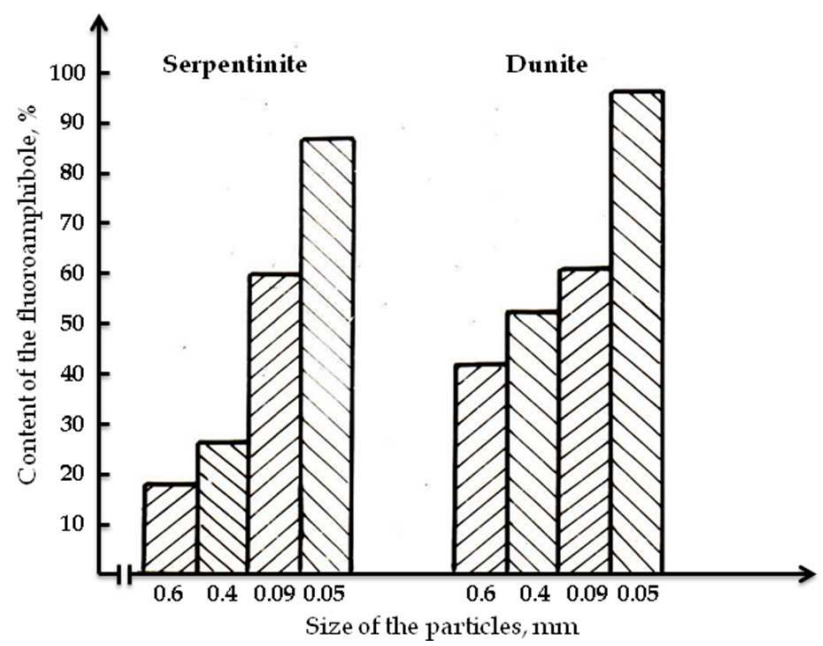

Fig. 4. The influence of the granule size of raw rocks serpentinite and dunite on the content of fluorosilicate in the end product.

The study of thermal conditions in the course of the synthesis showed that the most complete modification of rocks happen in the temperature range $850-920^{\circ} \mathrm{C}$ (Fig. 5).
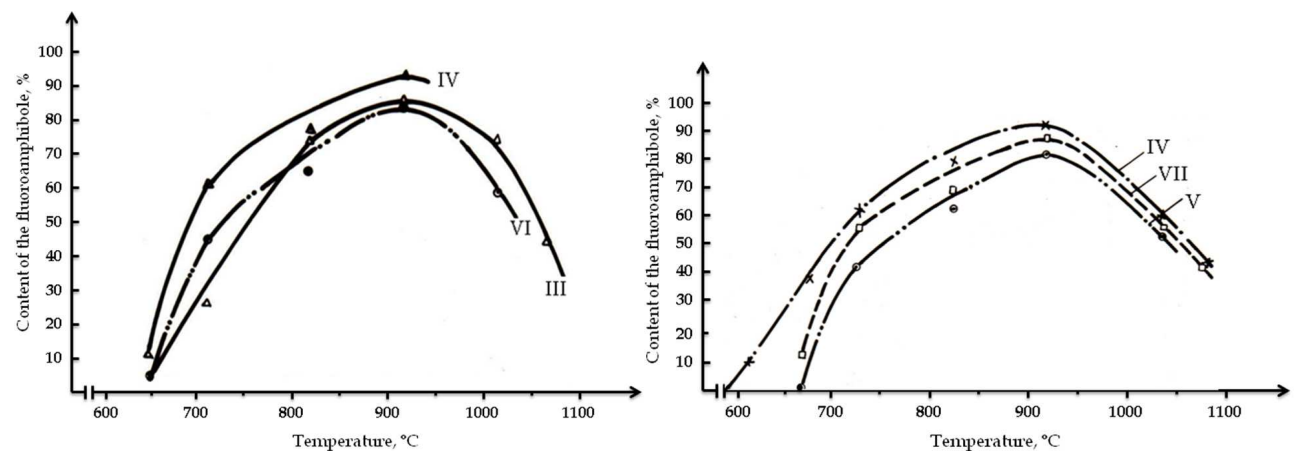

Fig. 5. The effect of heating on the yield of the fluoramphibole (exposure time $48 \mathrm{~h}$ ) in the reaction blends with: III -serpentinite, IV - calcinated serpentinite, V - dunite, VI peridotite, and VII - pyroxenite.

The starting temperature for fluoramphibole formation was lower in the blends, which were based on the rocks containing substantial amounts of orthosilicate (blends V and IV) and enstatite (blends VI and VII). The process was defined to have start temperature higher by $50-70^{\circ} \mathrm{C}$ within the blend (III) with coarse serpentine. The crystallization temperature was elevated in the blend VII owing to the presence of monoclinic pyroxens, e.g. diopside and diallage. 
The formation of FFS at $700-720^{\circ} \mathrm{C}$ was observed on the surface of end product obtained from dunite (blend V), and at $800-820^{\circ} \mathrm{C}$ in the reaction blends III, IV, VI, VII. In all blends heating upon $850-920^{\circ} \mathrm{C}$ led to elongation and thickening of fibres/needles in both surface 'brush' and basic mass of the product. At $1000-1100^{\circ} \mathrm{C}$ the fluoramphibole was crystallized in form of short-acicular and fine-prismatic crystals.

More intensively the solid-phase reactions proceeded at $900-920^{\circ} \mathrm{C}$, when the exposure lasted 24-36 h (Fig. 6). The processes were in fact accomplished by the exposure time of 36$48 \mathrm{~h}$.

The fibres were elongated from 0.01 to $0.4 \mathrm{~mm}$ by the time of exposure from 1 to $6 \mathrm{~h}$. The further prolongation of exposure by $12-48 \mathrm{~h}$ caused an increase in length of fibres within the basic mass and on the surface of the synthesized product.

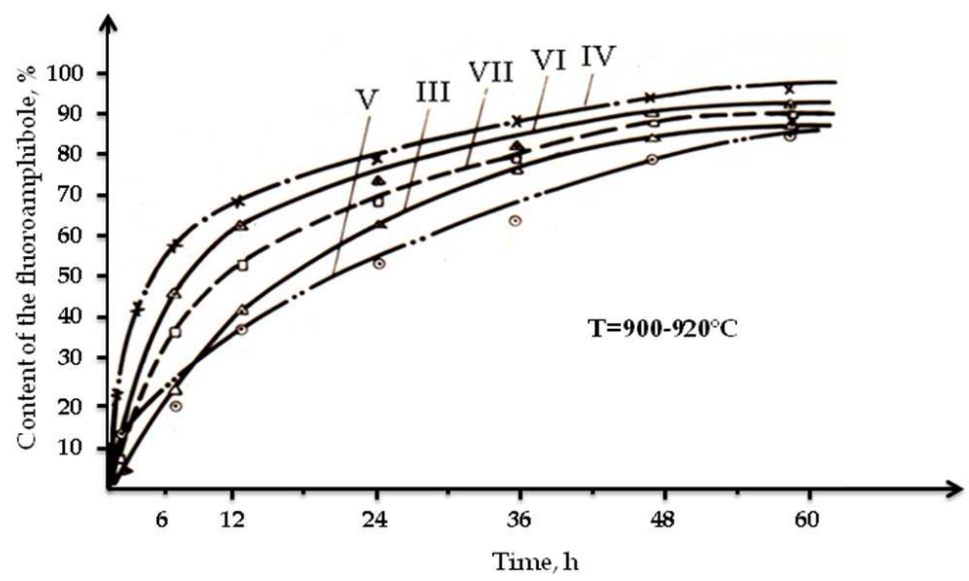

Fig. 6. The effect of the exposure time on the yield of the fluoramphibole in the reaction blends with: III -serpentinite, IV - calcinated serpentinite, V - dunite, VI - peridotite, and VII pyroxenite.

In summary, synthesized samples contained around $85-95 \%$ fluorosilicates in form of fibrous and fine-prismatic crystals. Their length in the basic mass of the product constituted 0.1-1.0 mm, and thickness - 0.01-5.00 $\mu \mathrm{m}$. Under certain conditions 5-30 mm long and 0.05$8.0 \mu \mathrm{m}$ thick fluoramphibole fibres form a monomineral 'brush' on the surface of synthesized product (Fig. 7).

The results of crystal-optical and X-ray phase assays demonstrated that the fluorosilicate in shape of acicular-fibrous crystals was a dominant phase in the samples obtained from the reaction blends containing high dispersed mining rocks (with granule size $\leq 50 \mu \mathrm{m}$ ) supplemented with around $10-30 \mathrm{wt} \%$ fluxes $(\mathrm{NaCl})$ at $850-920^{\circ} \mathrm{C}$, and within the exposure time 36-48 $\mathrm{h}$. The accompanying minerals in the products of synthesis were mainly represented by galite and sodium fluoride, as well as by $\mathrm{CaF}_{2}, \mathrm{MgF}_{2}, \mathrm{NaMgF}_{3}, \mathrm{NaFeF}_{4}$, glass, etc, in markedly lower concentrations. 

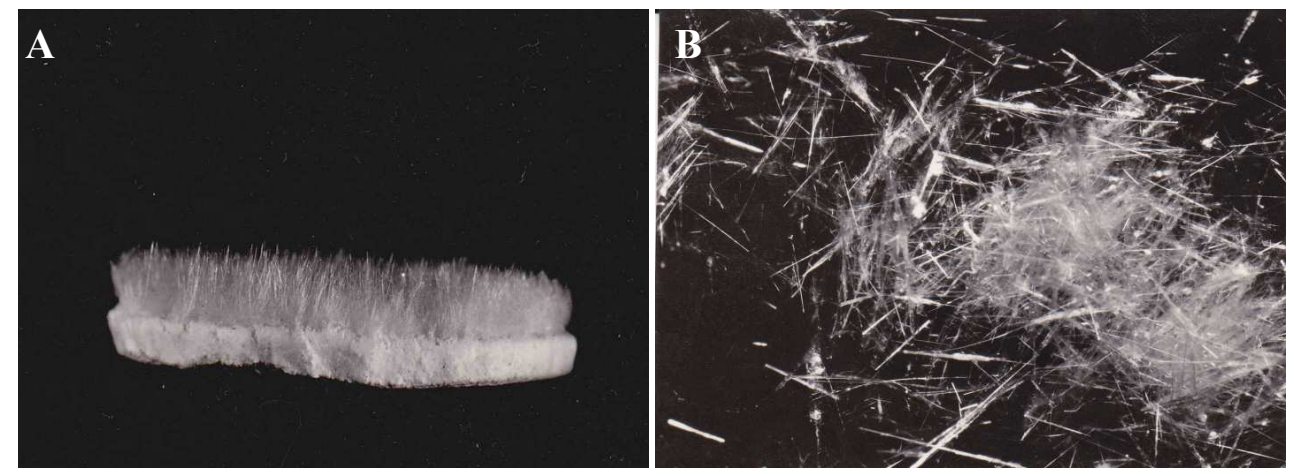

Fig. 7. Synthetic fibrous fluoramphibole from mining rock serpentinite: general view of the synthesis product $(A, 0.5 \mathrm{x})$ and fibrous crystals $(B, 0.5 \mathrm{x})$.

To better understand the features of solid phase synthesis from mining rocks we investigated some mechanisms of chemical and phase transformations occurring in the reaction blends as well as the kinetics of the process.

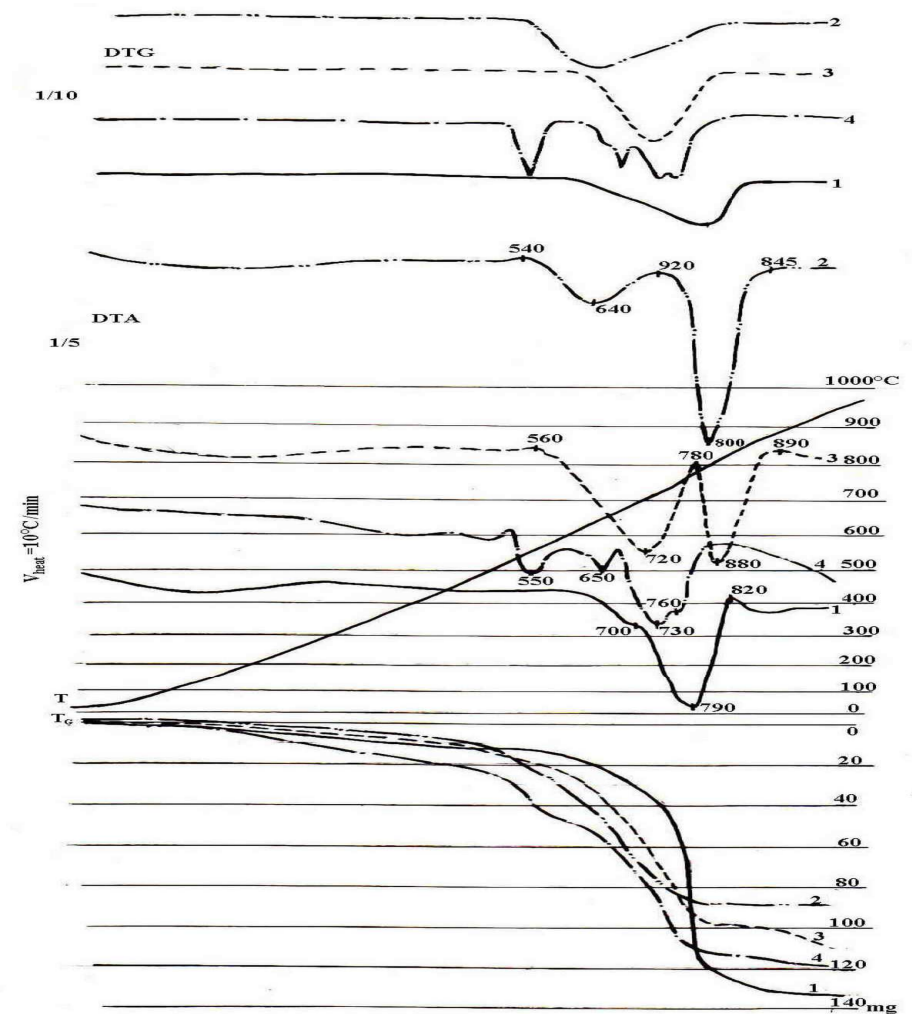

Fig. 8. DTG and DTA curves for the blends containing serpentinite (S, 1), S-NaF (2), S-NaCl (3), and $\mathrm{S}-\mathrm{Na}_{2} \mathrm{SiF}_{6}(4)$. 
The formation of asbestos-like ribbon-chain fluorosilicates (amphiboles) in the studied blends appeared to depend substantially on the chemical nature and crystal chemical characteristics of the initial reactants and, consequently, on the physicochemical features of their behaviour upon heating. In turn, this determines the mechanisms responsible for chemical interactions between precursors (in particular, for the character and sequence of chemical transformations) and for the characteristics of final products.

As discussed above, to reveal a correlation between the physic-chemical parameters of initial reactants and chemical and phase transformations during the synthesis of FFS from mining rocks, we studied the phase compositions of the products obtained by the treatment of the reaction blends I-VII under different thermal-temporal conditions. The intermediate and final products of heating were identified by X-ray powder diffraction and crystaloptical assays. Moreover, for a more exact interpretation of the data, the sequence of serpentinite transformations and the dinamics of chemical interactions between $S$ and sodium fluorosilicate $\left(\mathrm{Na}_{2} \mathrm{SiF}_{6}\right)$, halite $(\mathrm{NaCl})$, and sodium fluoride $(\mathrm{NaF})$ upon heating were investigated using thermal (Fig. 8, curves 1- 4), X-ray diffraction at room and high temperatures (Fig. 9), crystal-optical, and chemical assays.

The data on blend composition together with the results of these analyses are summarized in the table 4 . The transformations of the sodium fluorosilicate and its hardened samples, obtained by heating upon $600^{\circ} \mathrm{C}$ with exposure time 10 and 30 min were described using the crystal-optical, X-ray powder diffraction and thermal analyses (Khachatryan, 1969, Khachatryan and Karachanyan, 2000).

In the reaction blends within the temperatures range of $90-7500^{\circ} \mathrm{C}$ dehydration and dehydroxylation of serpentines chrysotile and antigorite (Fig. 8, curve 1), decomposition of olivine, and the transformation of magnetite (see Table 3) were found to proceed according to the reactions (7)-(10).

$$
\begin{aligned}
& 3 \mathrm{MgO} \cdot 2 \mathrm{SiO}_{2} \cdot 2 \mathrm{H}_{2} \mathrm{O} \stackrel{-2 \mathrm{H}_{2} \mathrm{O}}{400-620^{\circ} \mathrm{C}} 3 \mathrm{MgO} \cdot 2 \mathrm{SiO}_{2} \stackrel{2700^{\circ} \mathrm{C}}{\longrightarrow} \mathrm{Mg}_{2} \mathrm{SiO}_{4}+
\end{aligned}
$$

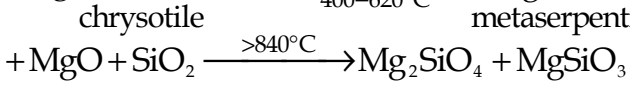

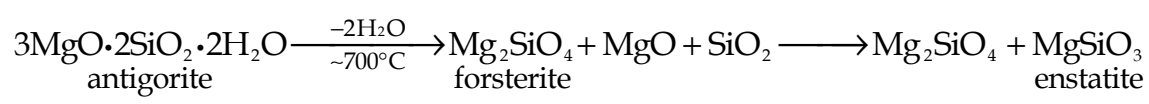

$$
\begin{aligned}
& (\mathrm{Mg}, \mathrm{Fe})_{2} \mathrm{SiO}_{4} \stackrel{<800^{\circ} \mathrm{C}}{\longrightarrow} 2 \mathrm{MgO} \cdot \mathrm{SiO}_{2}+\mathrm{Fe}_{2} \mathrm{O}_{3}+\mathrm{SiO}_{2} \\
& \text { olivine } \\
& \text { amorphous } \\
& \underset{\text { magnetite }}{\mathrm{FeO} \cdot \mathrm{Fe}_{2} \mathrm{O}_{3}} \stackrel{200-300^{\circ} \mathrm{C}}{\longrightarrow} \underset{\text { maghemite }}{\mathrm{Fe}_{2} \mathrm{O}_{3}} \stackrel{530-800^{\circ} \mathrm{C}}{\longrightarrow} \underset{\text { hematite }}{\mathrm{Fe}_{2} \mathrm{O}_{3}}
\end{aligned}
$$


We failed to observe the formation of complete X-ray amorphous phase during the decomposition of serpentinite under the conditions studied (Table 4, Fig. 9A), that was in line with the data obtained by Koltermann (1965).

\begin{tabular}{|c|c|c|c|c|}
\hline \multirow{2}{*}{$\begin{array}{l}\text { Initial } \\
\text { Blend }\end{array}$} & \multicolumn{3}{|c|}{ Conditions of treatment } & \multirow{2}{*}{ Products of treatment } \\
\hline & $\begin{array}{l}\text { temperature, } \\
{ }^{\circ} \mathrm{C}\end{array}$ & $\begin{array}{c}\text { exposure, } \\
\mathrm{h}\end{array}$ & $\begin{array}{l}\text { supplements, } \\
\text { wt } \%\end{array}$ & \\
\hline$S$ & 550 & 2 & - & Partially modified serpentine \\
\hline S & 650 & 2 & - & $\begin{array}{l}\text { Partially modified serpentine, } \\
\text { forsterite }\end{array}$ \\
\hline S & 800 & 2 & - & Forsterite, hematite \\
\hline $\mathrm{S}-\mathrm{NaCl}$ & 550 & 2 & 20 & $\begin{array}{l}\text { Serpentine, forsterite, ore mineral, } \\
\text { glass }\end{array}$ \\
\hline $\mathrm{S}-\mathrm{NaCl}$ & 800 & 2 & 20 & $\begin{array}{l}\text { Forsterite, enstatite, ore mineral, } \\
\text { glass, amphibole }\end{array}$ \\
\hline $\mathrm{S}-\mathrm{Na}_{2} \mathrm{SiF}_{6}$ & 700 & 2 & 20 & $\begin{array}{l}\text { Serpentine, NaMg-threechain silicate, } \\
\text { amphibole, forsterite, enstatite, } \\
\text { fluorides, ore mineral }\end{array}$ \\
\hline $\mathrm{S}-\mathrm{Na}_{2} \mathrm{SiF}_{6}$ & 800 & 2 & 20 & $\begin{array}{l}\text { Amphibole, NaMg-threechain silicate, } \\
\text { forsterite, enstatite, fluorides, ore } \\
\text { mineral }\end{array}$ \\
\hline $\mathrm{S}-\mathrm{Na}_{2} \mathrm{SiF}_{6}$ & 900 & 2 & 20 & Amphibole, fluorides, ore mineral \\
\hline
\end{tabular}

Table 4. The conditions and products of the thermal treatment of serpentinite (S) and the blends $\mathrm{S}-\mathrm{NaCl}, \mathrm{S}-\mathrm{Na}_{2} \mathrm{SiF}_{6}$ within the closed system.

The supplementation of the initial blends with fluorides $\mathrm{Na}_{2} \mathrm{SiF}_{6}$ and $\mathrm{NaF}$ or flux $\mathrm{NaCl}$ substantially affects the DTA curve of serpentinite. In this case, the introduction of $\mathrm{Na}_{2} \mathrm{SiF}_{6}, \mathrm{NaF}$ or $\mathrm{NaCl}$ to the serpentinite-containing blend reduced both the dehydration temperature and the temperature of maximal rate of dehydroxylation by 60,90 and $150^{\circ} \mathrm{C}$. This lowered the energy required for the activation of the decomposition process and widened the thermal field of the dehydration for this rock. The fine-fibrous phase of three-chain fluorosilicate $\mathrm{Na}_{2} \mathrm{Mg}_{4}\left[\mathrm{Si}_{6} \mathrm{O}_{16}\right] \mathrm{F}_{2}$ was formed in the closed bowl when heating the blend $\mathrm{S}-\mathrm{Na}_{2} \mathrm{SiF}_{6}$ upon $700^{\circ} \mathrm{C}$. The amount of this silicate was significantly reduced at $800^{\circ} \mathrm{C}$. 

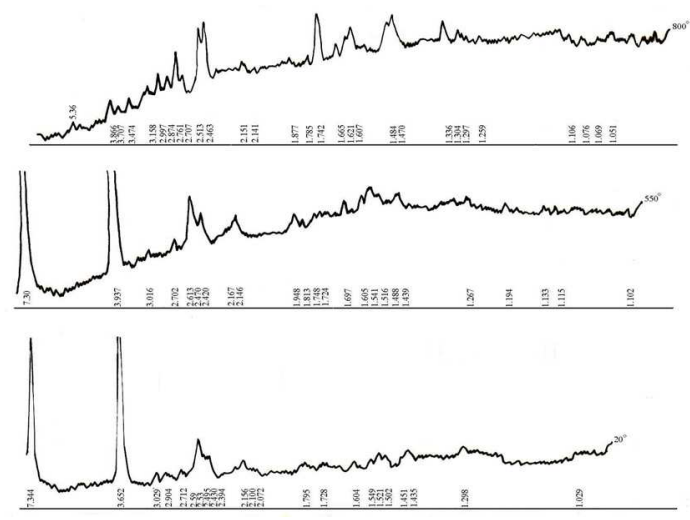

A
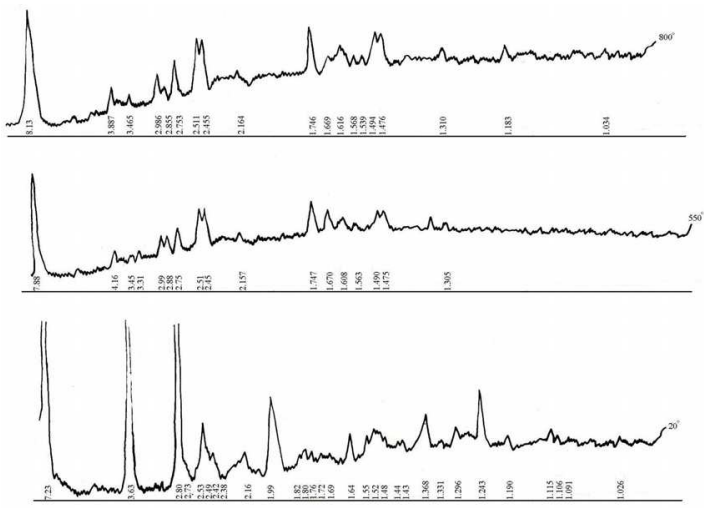

B
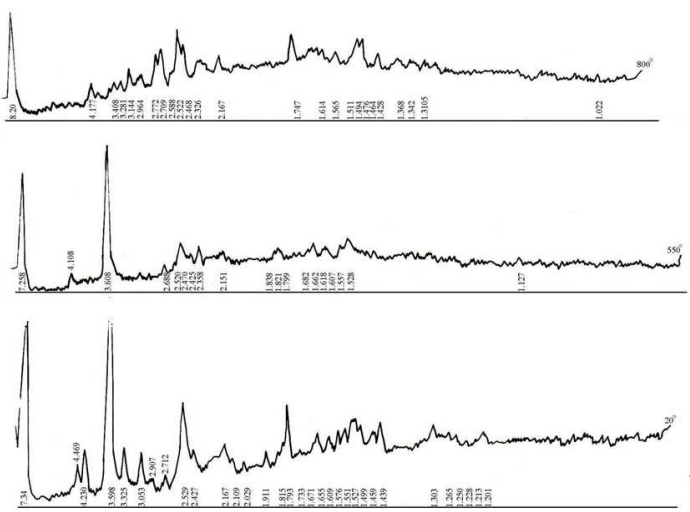

C

Fig. 9. Thermal X-ray diffraction patterns of serpentinite $(S, A)$ and the blends containing S$\mathrm{NaCl}(\boldsymbol{B})$ and $\mathrm{S}-\mathrm{Na}_{2} \mathrm{SiF}_{6}(\boldsymbol{C})$. The abscissa shows the value of $\mathrm{d} / \mathrm{n}$. Temperature $\left({ }^{\circ} \mathrm{C}\right)$, time (in min): 20; 550, 30; 800, 30. 
The decomposition of sodium fluorosilicate, which parallels the processes (7)-(10) occurring in the initial blends III-VII at the temperature above $400^{\circ} \mathrm{C}$, can be represented by the reactions (11)-(13):

$$
\begin{gathered}
. \mathrm{Na}_{2} \mathrm{SiF}_{6} \stackrel{540-560^{\circ} \mathrm{C}}{\longrightarrow} 2 \mathrm{xNaF}+(1-\mathrm{x}) \mathrm{Na}_{2} \mathrm{SiF}_{6}+x \mathrm{SiF}_{4} \uparrow . \\
\mathrm{SiF}_{4}+2 \mathrm{H}_{2} \mathrm{O} \stackrel{\geq 420^{\circ} \mathrm{C}}{\longrightarrow} \mathrm{SiO}_{2}+4 \mathrm{HF} \uparrow \\
3 \mathrm{SiO}_{2}+4 \mathrm{NaF} \stackrel{570-620^{\circ} \mathrm{C}}{\longrightarrow} 2 \mathrm{Na}_{2} \mathrm{SiO}_{3}+\mathrm{SiF}_{4} \uparrow
\end{gathered}
$$

The further increase in the temperature $\left(\geq 600{ }^{\circ} \mathrm{C}\right)$ was reported to result in the complete decomposition of $\mathrm{Na}_{2} \mathrm{SiF}_{6}$ with the formation of $\mathrm{NaF}$ (Khachatryan, 1969, Istomin, 1980).

Water vapour formed in the reactions (7) and (8) obviously exerted a catalytic effect on the chemical transformations occurring in the blends (Simons, 1950; Prodan et al., 1976; Tret'yakov, 1978). The hydrogen fluoride HF released in the reaction (12) facilitated the decomposition of initial minerals and products of thermal treatment of mining rocks, e.g. metaserpentine, forsterite, enstatite, amorphous $\mathrm{SiO}_{2}$, and intermediate compounds (Ryss, 1956; Butt et al., 1965; Kogarko and Krigman, 1981). The possible interactions are summarized in the reactions (14)-(17).

$$
\begin{gathered}
\begin{array}{c}
3 \mathrm{MgO} \cdot 2 \mathrm{SiO}_{2} \\
\text { metaserpentine }
\end{array} \\
\underset{\mathrm{SiO}}{2}+6 \mathrm{HF} \longrightarrow \mathrm{MgF}_{2}+2 \mathrm{SiO}_{2}+3 \mathrm{H}_{2} \mathrm{O} \uparrow \\
\text { amorphous } \\
2 \mathrm{MgF}_{2}+\mathrm{SiO}_{2} \longrightarrow 2 \mathrm{MgO}+\mathrm{SiF}_{4} \uparrow \\
\mathrm{MgF}_{2}+\mathrm{SiO}_{2}+\mathrm{H}_{2} \mathrm{O}_{\text {vapour }} \longrightarrow
\end{gathered}
$$

The presence of $\mathrm{NaCl}$ in the mixture decreased the elimination of $\mathrm{SiF}_{4}$ (Istomin, 1980) through the formation of the unstable intermediate compound $\mathrm{Na}_{2} \mathrm{SiF}_{4} \mathrm{Cl}_{2}$, as shown in the reaction (18):

$$
2 \mathrm{NaCl}+\mathrm{SiF}_{4} \longrightarrow \mathrm{Na}_{2} \mathrm{SiF}_{4} \mathrm{Cl}_{2}
$$

In the products of treatment of the initial blends at $650-800^{\circ} \mathrm{C}$, one of the accompanying minerals was fluornorbergite. Additionally to the reaction (3), this mineral could be formed in the reaction (19):

$$
\underset{\text { enstatite }}{\mathrm{MgSiO}_{3}}+\mathrm{MgF}_{2}+\mathrm{MgO} \longrightarrow \underset{\text { fluornorbergite }}{\mathrm{Mg}_{2} \mathrm{SiO}_{4} \cdot \mathrm{MgF}_{2}}
$$


The compounds formed in these reactions (metaserpentine, forsterite, enstatite, threechain fluorsilicate, fluornorbergite, $\mathrm{SiO}_{2}$, fluorides and etc.) possessed high reactivity. Forsterite and fluornorbergite contained certain elements of the fluoramphibole structure; enstatite had a structure similar to the fluoroamphibole, whereas NaMg-threechain fluorosilicate resembled the fluoramphibole by its structure and chemical composition. These factors likely favoured the formation of fluoramphibole at relatively low temperatures ( 600 $\left.750^{\circ} \mathrm{C}\right)$. The fluoramphibole formed at these temperatures was defined by low content of iron. Further rise in the temperature promoted the formation of intermediate compounds: $\mathrm{Na}_{2} \mathrm{FeF}_{4}, \mathrm{Na}_{3} \mathrm{FeF}_{6}, \mathrm{NaMgF}_{3}, \mathrm{CaF}_{2}$, etc (Simons, 1950; Ryss, 1956). It is to note, that the formation of fluorosilicates occurred uniformly throughout the whole volume of the blends within relatively wide range of temperatures $\left(600-950^{\circ} \mathrm{C}\right)$.

The prolongation of treatment from 1 to $48 \mathrm{~h}$ at $900-920^{\circ} \mathrm{C}$ and the elevation of the temperature from 600 to $920^{\circ} \mathrm{C}$ led to the elongation and thickening of fluoramphibole fibres, i.e. formation of needles, and to the increase in the refractive index of fibres and needles from $n_{m}=1.582$ to $n_{m}=1.618$. These changes might result from the complexification of chemical compositions of fluoramphiboles, e.g. their enrichment with $\mathrm{Fe}^{2+}, \mathrm{Fe}^{3+}$, $\mathrm{Ca}^{2+}, \mathrm{Cr}^{3+}, \mathrm{Al}^{3+}$ and other cations, which promotes the yield of more isometric crystals of the product. Furthermore, the recrystallization of the fluoramphibole particles originated from olivine, forsterite, enstatite, and other minerals in the composition of $\mathrm{D}, \mathrm{S}_{\text {calcin, }} \mathrm{Px}$, and $\mathrm{P}$ at low temperatures at the initial stages of solid-phase synthesis, might influence the final shape of crystals. Altogether, this indicated, that the structures of fluoramphibole were formed in the course of sequential transformation of initial and intermediate compounds and that the elevation of process temperature together with prolongation of synthesis favoured an improvement of the crystal lattice in fluorosilicates (Godovikov, 1973).

Crystal-optic investigation of the products hardened at $550^{\circ} \mathrm{C}$ estimated the presence of melt in the studied systems. The generation of liquid phase in these conditions apparently was facilitated by the melting of $\mathrm{FeCl}_{3}$ released in the schematic reaction (20):

$$
\mathrm{Fe}_{3} \mathrm{O}_{4}+\mathrm{NaCl} \longrightarrow \mathrm{FeCl}_{3}+\mathrm{Na}_{2} \mathrm{O}
$$

An increase in the amount of liquid phase was associated with the further elevation in the temperature and occurred due to the melting of solid constituents of the initial mixtures and formed eutectic blends (Sharma and Johnson, 1962; Levin et al., 1964; Kogarko et al., 1968; Kuvakin and Rod'kina, 1971).

Thus, within the temperature range of $400-1000^{\circ} \mathrm{C}$ the solid-phase interactions proceeded with the participation of both gaseous phase and melt, i.e. the crystals of fibrous fluorosilicates grew by 'feeding' from the melt and the gaseous phase. Depending on the conditions of synthesis the gaseous phase may contain $\mathrm{SiF}_{4}, \mathrm{HF}$, and $\mathrm{H}_{2} \mathrm{O}$ (see the reactions (11)-(17)). The mole percentage of $\mathrm{SiF}_{4}$ in the initial blends and in the gaseous phase was raised by the growth of the ratio F/O (Kogarko et al., 1968). The presence and, moreover, the excess of $\mathrm{Cl}^{-}$intensified the participation of gaseous phase in the formation of fluorcontaining compounds $\left(\mathrm{NaMgF}_{3}, \mathrm{MgSiF}_{6}, \mathrm{SiF}_{4}, \mathrm{HF}\right)$ and $\mathrm{Na}_{2} \mathrm{SiCl}_{6}$ as the product of the sequential reactions: 


$$
\begin{gathered}
\mathrm{NaCl}+\mathrm{HF} \longrightarrow \mathrm{NaF}+\mathrm{HCl} \uparrow \\
\underset{\mathrm{SiO}}{\text { amorphous }}+4 \mathrm{HCl} \longrightarrow \mathrm{SiCl}_{4}+2 \mathrm{H}_{2} \mathrm{O} \uparrow \\
2 \mathrm{NaCl}+\mathrm{SiCl}_{4} \longrightarrow \mathrm{Na}_{2} \mathrm{SiCl}_{6}
\end{gathered}
$$

In gaseous phase $\mathrm{Na}_{2} \mathrm{SiCl}_{6}$ was stable under the described conditions (see also Wartenberg, 1953). Mass-spectrometric analysis of products evaporated from the alloys in the system $\mathrm{NaF}-\mathrm{MgF}_{2}$ determined the presence of $\mathrm{NaF}, \mathrm{Na}_{2} \mathrm{~F}_{2}$, and $\mathrm{Na}_{3} \mathrm{~F}_{3}$ at $800^{\circ} \mathrm{C}$ (Nikitin et al., 1973). The appearance of sodium in the gaseous phase might also result from the evaporation of $\mathrm{NaCl}$ at $750^{\circ} \mathrm{C}$ in open air and at $700^{\circ} \mathrm{C}$ in the stream of water vapour (Spitsyn et al., 1952).

The complex magnesium fluoride $\mathrm{MgSiF}_{6}$, which released in the reaction (24) (Kogarko and Krigman, 1981), expressed significant vapour pressure at $750-1100^{\circ} \mathrm{C}$.

$$
\mathrm{MgF}_{2}+\mathrm{SiF}_{4} \longrightarrow \mathrm{MgSiF}_{6}
$$

High vapour pressure seems to be the characteristic property of the complex fluorides $\left(\mathrm{MgSiF}_{6}, \mathrm{Na}_{2} \mathrm{FeF}_{4}, \mathrm{Na}_{2} \mathrm{FeF}_{6}, \mathrm{NaMgF}_{3}\right.$, etc) under the mentioned thermal conditions (Eitel et al., 1956). Using the mass-spectrometric assay a number of researchers have distinguished the silicium oxyfluoride $\mathrm{SiOF}_{2}$ in the gaseous phase of fluorosilicate systems (Nikitin et al., 1973; Novoselova et al., 1964; Novoselova and Azhikina, 1966).

Thus, all cations required for fibrous fluoramphibole synthesis were represented in the gaseous phase. The concentration of these cations depended on the composition of the reaction blend and on thermal-temporal parameters of synthesis. This was confirmed by the formation of fibrous fluoramphiboles on the surface of the main treatment product at $\sim 700$ $720^{\circ} \mathrm{C}$ (blend V) and at $\sim 800-820^{\circ} \mathrm{C}$ (blends III, IV, VI, VII). Furthermore, an increase in the number, length, and thickness of fibers and needles forming a dense 'brush' accompanied the temperature raise up to $850-920^{\circ} \mathrm{C}$ and the prolongation of the synthesis up to $24-36 \mathrm{~h}$.

The formation of fibrous fluoramphiboles at above $800^{\circ} \mathrm{C}$ proceeded apparently with the participation of the gaseous phase characterized by higher content of iron. The putative chemical interactions can be reflected by the reactions (25)-(28):

$$
\underset{\text { norbergite }}{\mathrm{Mg}_{2} \mathrm{SiO}_{4} \cdot \mathrm{MgF}_{2}+\mathrm{Na}_{3} \mathrm{FeF}_{6}+\mathrm{MgSiO}_{3}+7 \mathrm{SiO}_{2} \longrightarrow} \underset{\mathrm{NaMg} \text {-fluorarfvedsonite }}{\mathrm{Na}_{3} \mathrm{Mg}_{4} \mathrm{Fe}^{3+}\left[\mathrm{Si}_{8} \mathrm{O}_{22}\right] \mathrm{F}_{2}}
$$

$$
\begin{aligned}
& \underset{\text { forsterite }}{2\left(\mathrm{Mg}_{2} \mathrm{SiO}_{4}\right)}+\mathrm{NaFeF}_{4}+2 \mathrm{NaF}+4 \mathrm{SiO}_{2} \longrightarrow \mathrm{Na}_{3} \mathrm{Mg}_{4} \mathrm{Fe}^{3+}\left[\mathrm{Si}_{8} \mathrm{O}_{22}\right] \mathrm{F}_{2} \\
& \mathrm{Mg}_{2} \mathrm{SiO}_{3}+2 \mathrm{NaF}+\mathrm{NaFeF}_{4}+2 \mathrm{MgO}+7 \mathrm{SiO}_{2} \longrightarrow \mathrm{Na}_{3} \mathrm{Mg}_{4} \mathrm{Fe}^{3+}\left[\mathrm{Si}_{8} \mathrm{O}_{22}\right] \mathrm{F}_{2}
\end{aligned}
$$




$$
\underset{\text { threechain fluorsilicate }}{\mathrm{Na}_{2} \mathrm{Mg}_{4}\left[\mathrm{Si}_{6} \mathrm{O}_{16}\right] \mathrm{F}_{2}}+\mathrm{NaFeF}_{4}+2 \mathrm{SiO}_{2} \longrightarrow \mathrm{Na}_{3} \mathrm{Mg}_{4} \mathrm{Fe}^{3+}\left[\mathrm{Si}_{8} \mathrm{O}_{22}\right] \mathrm{F}_{2}
$$

With the temperature raise above $1150^{\circ} \mathrm{C}$ fluoroamphibole partially decayed with the formation of magnesium- ortosilicate, spinel, tridimite, and ore mineral.

The differences during fluorosilicate synthesis observed for serpentinite-contatining blends supplemented with either $\mathrm{NaF}$ or $\mathrm{Na}_{2} \mathrm{SiF}_{6}$, might originate from the circumstance that in the NaF-added blends thermal-temporal parameters of dehydration of initial minerals do not match with those of $\mathrm{NaF}$ hydrolysis and with conditions, under which the content of $\mathrm{NaF}$ in the gaseous phase reached conspicuous values.

Our results demonstrated the complex character of interaction between the precursors in the studied blends during the synthesis of asbestos-like fluorosilicates. In the course of solidphase reactions, the gaseous phase participated actively within the temperatures range of $\sim 400-900^{\circ} \mathrm{C}$, whereas the liquid phase (the melt of mainly halogen-containing composition) played the leading role at temperatures above $\geq 600^{\circ} \mathrm{C}$. The reactions of fibrous fluoroamphibole formation proceeded with a considerable rate at relatively low temperatures $\left(850-920^{\circ} \mathrm{C}\right)$ owing to the presence of the gaseous and liquid phases. The high reactivity of the blends could be explained by mineralogical composition and texturestructure features of the mining rocks: $S, D, P$, and pyroxenite.

In summary, we suggest that the process of fibrous fluorosilicate formation from mining rocks involved a sequence of complex phase transformations and chemical reactions in combination with structural transformations and recrystallization.

The treatment of magnesium silicate-containing rocks under pyrogenic conditions led to the crystallization of fluorosilicates in the form of fibrous-, thin-, and thick- prismatic crystals of the various length (Fig. 10).

Our investigations indicated that the morphology of fluoramphibole crystals was highly influenced by the following factors: the mineralogical composition of initial rocks, content and character of fluorine-containing components and flux in the initial mixtures, the dispersion rate of rocks, and the temperature and duration of the synthesis.

Morphogenetic patterns of the crystallization process, which take place at the end stage of solid-phase interactions, were defined by succession of structural components of crystalline compounds involved in the reaction. In solid-phase reactions the fluoroamphibole was shaped in form of fibers in case of emergence of intermediate products such as forsterite and fluornorbergite, which contain the oxygen octahedrons of magnesium. The latter by their size and symmetry resemble polyhedrons $M(1-3)$ in the structure of amphiboles. Another intermediate product - threechain FFS, bears as a basic structural component the ribbons of $\left[\mathrm{Si}_{6} \mathrm{O}_{16}\right]_{-\infty}^{8-}$ composition, which are represented by three polar tetrahedron (pyroxen) chains connected by common oxygen atoms. Collectively, the fibrous shape of fluoramphibole was thereby determined by a complex of intermediate products expressing proximity of structures and compositions. 


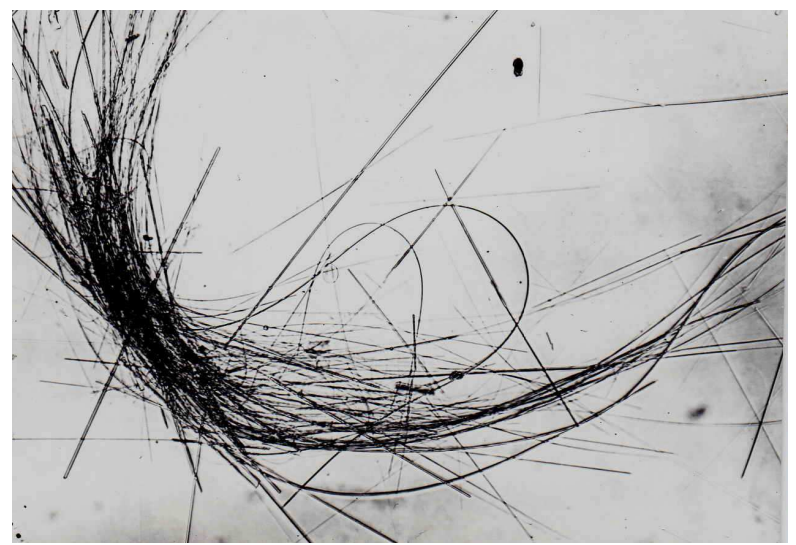

Fig. 10. Micrograph of synthetic fibrous fluorosilicates (x 110).

\begin{tabular}{|c|c|c|c|c|}
\hline \multirow{2}{*}{$\begin{array}{c}\text { Chemical } \\
\text { composition, } \\
\text { wt\% }\end{array}$} & \multicolumn{4}{|c|}{ Fluorosilicates obtained from the blends containing: } \\
\cline { 2 - 5 } & Serpentinite & Peridotite & Dunite & Pyroxenite \\
\hline $\mathrm{SiO}_{2}$ & 58.36 & 58.20 & 58.7 & 55.11 \\
\hline $\mathrm{Al}_{2} \mathrm{O}_{3}$ & 0.30 & 1.25 & 0.68 & 2.10 \\
\hline $\mathrm{Fe}_{2} \mathrm{O}_{3}$ & 3.08 & 2.83 & 3.83 & 6.05 \\
\hline $\mathrm{FeO}$ & 0.05 & 0.12 & 0.05 & traces \\
\hline $\mathrm{Cr}_{2} \mathrm{O}_{3}$ & 0.20 & 0.08 & 0.16 & 0.4 \\
\hline $\mathrm{MgO}$ & 26.31 & 28.00 & 25.1 & 20.15 \\
\hline $\mathrm{CaO}$ & 1.86 & 0.88 & 0.87 & 1.59 \\
\hline $\mathrm{Na}_{2} \mathrm{O}$ & 7.12 & 5.83 & 7.10 & 11.39 \\
\hline $\mathrm{H}_{2} \mathrm{O}^{+}$ & - & - & - & - \\
\hline $\mathrm{H}_{2} \mathrm{O}^{-}$ & 0.28 & - & 0.61 & - \\
\hline $\mathrm{F}$ & 4.09 & 4.70 & 4.84 & 4.52 \\
\hline $\mathrm{Sum}$ & 101.65 & 101,33 & 101.94 & 101.53 \\
\hline $\mathrm{F}=\mathrm{O}_{\text {equivalent }}$ & 1.72 & 1.92 & 2.00 & 1.9 \\
\hline$\sum$ & 99.93 & 99.11 & 99.94 & 99.63 \\
\hline
\end{tabular}

Table 5. The chemical composition of obtained fibrous fluorosilicates.

Synthesized FFS by their chemical composition (Table 5), structure (Table 6, Fig 11), and physical-chemical properties (Table 7) related to NaMg-arfvedsonite asbestos (Hodgson, 1965; Chigareva, 1967; Grigor'eva et al., 1975). Crystallochemical formulas of fibrous fluorosilicates synthesized in serpentinite-, dunite-, peridotite- and pyroxnite-containing blends corresponded respectively to:

$\mathrm{Na}_{1.90} \mathrm{Ca}_{0.30} \mathrm{Mg}_{5.40} \mathrm{Fe}^{3+}{ }_{0.32} \mathrm{Fe}^{2+}{ }_{0.006} \mathrm{Cr}^{3+}{ }_{0.02} \mathrm{Al}_{0.05} \mathrm{Si}_{8} \mathrm{O}_{22}\left(\mathrm{~F}_{1.8} \mathrm{O}_{0.34}\right)$,

$\mathrm{Na}_{1.55} \mathrm{Ca}_{0.13} \mathrm{Mg}_{5.70} \mathrm{Fe}^{3+}{ }_{0.28} \mathrm{Fe}^{2+}{ }_{0.002} \mathrm{Cr}^{3+}{ }_{0.01} \mathrm{Al}_{0.09} \mathrm{Si}_{8} \mathrm{O}_{22} \mathrm{~F}_{2}$,

$\mathrm{Na}_{1.90} \mathrm{Ca}_{0.12} \mathrm{Mg}_{5.10} \mathrm{Fe}^{3+}{ }_{0.40} \mathrm{Cr}^{3+}{ }_{0.01} \mathrm{Al}_{0.11} \mathrm{Si}_{8} \mathrm{O}_{22} \mathrm{~F}_{2}$ ，

$\mathrm{Na}_{3} \mathrm{Ca}_{0.24} \mathrm{Mg}_{4.24} \mathrm{Fe}^{3+}{ }_{0.67} \mathrm{Cr}^{3+}{ }_{0.04} \mathrm{Al}_{0.35} \mathrm{Si}_{7.71} \mathrm{O}_{22} \mathrm{~F}_{2}$. 


\begin{tabular}{|c|c|c|c|c|c|c|c|c|}
\hline \multirow{2}{*}{ Fluoramphibole composition } & \multicolumn{4}{|c|}{ Parameters of crystal lattice } & \multicolumn{4}{|c|}{ Optical constants } \\
\hline & $\mathrm{a}, \mathrm{nm}$ & $\mathrm{b}, \mathrm{nm}$ & $\mathrm{c}, \mathrm{nm}$ & $\beta$ & $\mathrm{Ng}$ & $\mathrm{Np}$ & $\mathrm{Ng}-\mathrm{Np}$ & $\mathrm{cNg}$ \\
\hline $\begin{array}{l}\mathrm{Na}_{1.90} \mathrm{Ca}_{0.30} \mathrm{Mg}_{5.40} \mathrm{Fe}^{3+}{ }_{0.32} \mathrm{Fe}^{2+}{ }_{0.006} \mathrm{Cr}^{3+}{ }_{0.02} \mathrm{Al}_{0.05} \mathrm{Si}_{8} \\
\mathrm{O}_{22}\left(\mathrm{~F}_{1.8} \mathrm{O}_{0.34}\right)\end{array}$ & 0.972 & 1.788 & 0.530 & $103^{\circ} 44^{\prime}$ & 1.615 & 1.600 & 0.015 & $24^{\circ}$ \\
\hline $\begin{array}{l}\mathrm{Na}_{1.55} \mathrm{Ca} \mathrm{Ca}_{0.3} \mathrm{Mg}_{5.70} \mathrm{Fe}^{3+}{ }_{0.28} \mathrm{Fe}^{2+}{ }_{0.002} \mathrm{Cr}^{3+}{ }_{0.01} \mathrm{Al}_{0.09} \mathrm{Si} 8 \\
\mathrm{O}_{22} \mathrm{~F}_{2}\end{array}$ & 0.968 & 1.770 & 0.522 & $103^{\circ} 30^{\prime}$ & 1.594 & 1.583 & 0.011 & $24^{\circ}$ \\
\hline $\mathrm{Na}_{1.90} \mathrm{Ca}_{0.12} \mathrm{Mg}_{5.10} \mathrm{Fe}^{3+}{ }_{0.40} \mathrm{Cr}^{3+}{ }_{0.01} \mathrm{Al}_{0.11} \mathrm{Si}_{8} \mathrm{O}_{22} \mathrm{~F}_{2}$ & 0.966 & 1.784 & 0.523 & $103^{\circ} 11^{\prime}$ & 1.618 & 1.600 & 0.018 & $24^{\circ}$ \\
\hline $\mathrm{Na}_{3} \mathrm{Ca} 0.24 \mathrm{Mg}_{4.24} \mathrm{Fe}^{3+}{ }_{0.67} \mathrm{Cr}^{3+}{ }_{0.04} \mathrm{Al}_{0.35} \mathrm{Si}_{7.71} \mathrm{O}_{22} \mathrm{~F}_{2}$ & 0.964 & 1.783 & 0.524 & $103^{\circ} 7^{\prime}$ & 1.612 & 1.594 & 0.018 & $24^{\circ}$ \\
\hline
\end{tabular}

Table 6. Parameters of crystal lattice and optical characteristics of synthesized fibrous fluorosilicates.

\begin{tabular}{|l|c|c|c|c|c|c|}
\hline \multirow{2}{*}{$\begin{array}{l}\text { Fibrous } \\
\text { fluorosilicates }\end{array}$} & \multicolumn{2}{|l|}{ Thermal properties, T, ${ }^{\circ} \mathrm{C}$} & \multicolumn{2}{|c|}{$\begin{array}{l}\text { Chemical resistance: } \\
\text { weight loss (in wt \%) }) \\
\text { after boiling }(4 \mathrm{~h}) \text { in: }\end{array}$} & $\begin{array}{c}\text { Adsorption of water vapour: } \\
\text { weight gain (in wt \%) at air } \\
\text { water vapour pressure 16.4 } \\
\text { mm Hg }\end{array}$ \\
\cline { 2 - 8 } & Decomposition & Melting & $\mathrm{HCl}$ & $\mathrm{KOH}$ & in 24 h & in 30 days \\
\hline From serpentinite & $980-1070$ & $1180-1230$ & 5.40 & 0.80 & 3.20 & 3.85 \\
\hline From dunite & $960-1000$ & $1160-1180$ & - & - & 2.40 & 2.70 \\
\hline From peridotite & $970-1050$ & - & 4.75 & 0.80 & 3.00 & 3.60 \\
\hline $\begin{array}{l}\text { Crocidolite } \\
\text { Hodgson, 1965 }\end{array}$ & $550-700$ & 800 & 8.0 & - & - & - \\
\hline $\begin{array}{l}\text { NaMg-fluorrichterite } \\
\text { Grigor'eva et al., 1975 }\end{array}$ & $950-1000$ & $1170-1190$ & 8.6 & 0.1 & - & - \\
\hline $\begin{array}{l}\text { NaMg- } \\
\text { fluorarfvedsonite } \\
\text { Grigor' eva et al., 1975 }\end{array}$ & $940-1000$ & $1000-1060$ & 8.40 & 1.50 & - & - \\
\hline
\end{tabular}

Table 7. Physical-chemical properties of fibrous fluorosilicates obtained from mining rocks and chemical reactants.

Fluoramphiboles were crystallized mainly in the form of fibres and needles, rarely as dissociated aggregates, which were formed by non-splited bundled fibres (Fig. 10, 11). By their size the fibres and needles in the basic mass were inferior to the crystals in the 'brush'. Thinner crystals were obtained from the blend with serpentinite, while the thicker ones from pyroxenite.

Electron-microscopic studies revealed that fluorosilicate microcrystals had the form of a ribbon extended by axis ' $c$ '.

The fibrous fluorosilicates obtained in our study from mining rocks did not concede by their properties to the fibrous fluoramphiboles synthesized from chemical reactants. Furthermore, the thermal properties and chemical resistance of fluorosilicates from mining rocks were better than those of natural asbestos crocidolite. The decomposition temperature of fluorosilicates from mining rocks was by $\sim 120-180^{\circ} \mathrm{C}$ higher compared with the natural and synthetic hydroxyl amphyboles (Hodgson, 1965; Khachatryan, 1969; Grigor'eva et al., 1975). 

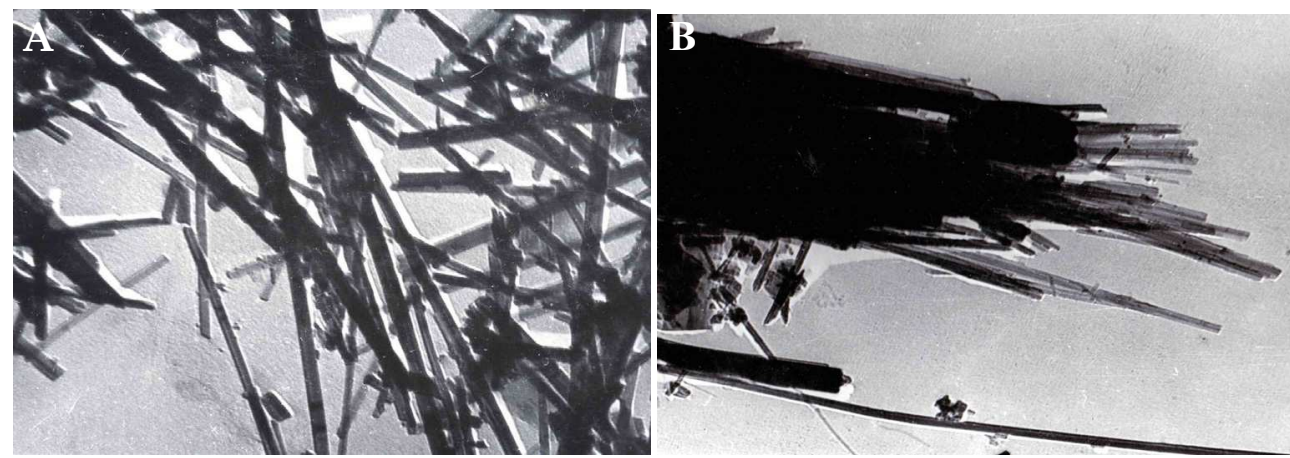

Fig. 11. Electron-microscopic images of fibrous fluorosilicate synthesized from serpentinite in form of fibres $(A, 18000 \mathrm{x})$ and dissociated aggregate $(B, 25000 \mathrm{x})$.

\section{Comparative analysis of solid-phase synthesis from mining rocks and chemical reactants}

The described approach to obtain fibrous fluorosilicates of NaMg-fluorarfvedsonite composition by solid-phase synthesis from mining rocks revealed a line of advantages. First, it utilizes less expensive initial blends, which contain inexpensive and affordable mining rocks instead of expensive chemical reactants and pure mineral roducite. Second, the mining rocks and other supplements in our method can be used per se, i.e. do not require preliminary treatment such as burning or drying, in contrast to the solid-phase synthesis from reactants and minerals. Third, the use of mining rocks enables the temperature of synthesis to be $\sim 100-130^{\circ} \mathrm{C}$ lower when compared with other conventional methods. Forth, the latter simplifies the technology and reduces the costs of synthesis. Fifth, the fibrous fluorosilicates synthesized from mining rocks express better physical-chemical properties, i.e. they are more thermostable and have higher chemical resistance.

\section{Practical outcome and perspectives of solid-phase synthesis of fibrous fluorosilicates from mining rocks}

We developed the method of synthesis of new fibrous crystalline materials, i.e. fluorosilicates of amphibole group, from natural feedstocks. By their texture these materials resemble natural amphibole asbestos, by chemical resistance in acidic and alkaline media, and by sorptive properties they do not concede to natural asbestos and synthetic fibrous fluoramphiboles obtained from reactants and pure minerals. By thermostability they substantially rank over natural amphibole asbestos (see decomposition temperatures in table 7).

This experimental approach was completely reproducible in large-scale laboratory set-ups, where the scales of the experiments were 20-30 times higher. Further, we plan to test this approach in preindustrial environment, as well as to employ the obtained fibrous fluorosilicates as fillers for creation of new composite materials based on organic, silicorganic, alumophosphate, etc, matricies. Such composite materials are utilized in the different fields of the modern technique to obtain thermostable clays, rubber, new pressed 
materials with valuable physic-mechanical properties, etc. Synthesized fibrous fluorosilicates can be also used as adsobtive substances for the extraction of heavy metal cations from acidic and alkaline water solutions and for the regeneration of specific elements during the sewage treatment in industry.

\section{Conclusion}

The possibility to synthesize inorganic non-stoichiometric fibrous fluorosilicates from inexpensive and readily affordable complex non - stoichiometric raw material such as magnesium silicate-containing mining rocks has been shown for the first time using the approach of the solid-phase synthesis. We determined the optimal conditions of the synthesis from serpentinite, calcinated serpentinite, dunite, pyroxenite, and peridotite. The fibrous fluorosilicates of NaMg-fluorarfvedsonite composition $\left(\mathrm{Na}_{3} \mathrm{Mg}_{4} \mathrm{Fe}^{3+}\left[\mathrm{Si}_{8} \mathrm{O}_{22}\right] \mathrm{F}_{2}\right.$ were synthesized by employing precursors with different chemical and mineralogical compositions. Obtained silicates displayed different rate of $\mathrm{Na}+\rightarrow \mathrm{Ca}^{2+}, \mathrm{Mg}^{2+} ; \mathrm{Mg}^{2+} \rightarrow \mathrm{Fe}^{2+}$; $\mathrm{Fe}^{3+} \rightarrow \mathrm{Cr}^{3+}, \mathrm{Al}^{3+} ; \mathrm{Si}^{4+} \rightarrow \mathrm{Al}^{3+}$ substitutions.

We estimated that mineralogical composition of initial rocks affected the lower limit of the temperature field in the course of fluoramphibole formation and the intensity of the process, as well as determined the maximal rate of rock transformation to the fluorosilicates and the required content of fluorine in the initial blend.

The reaction blends based on the mining rocks possessed a high reactivity, owing to which the fibrous fluorosilicates were synthesized at lower temperature (around $100-130^{\circ} \mathrm{C}$ ) and the duration of the synthesis was shortened several fold. The capability of the investigated rocks to be transformed into the fluoramphibole decreased within the following line: dunite - flamed serpentinite - peridotite - serpentinite - pyroxenite. The same capability of minerals included in the composition of mining rocks became extinct within the line: olivine enstatite -serpentine- monoclinic pyroxenes (diopside, diallag). The maximal yield ( 92\%) of fibrous fluorosilicates was observed in the reaction blend based on the dunite rock and supplemented with halogen-containing constituents $\mathrm{Na}_{2} \mathrm{SiF}_{6}$ and $\mathrm{NaCl}$. It is to note, that growing scale of the experiments resulted in increased yield of long-fiber fluorosilicate.

Fibrous fluorosilicate formation within the temperature range of $600-1000^{\circ} \mathrm{C}$ was demonstrated to result from complex non-stoichiometric reactions developing through sequential and parallel stages with the contribution of liquid and gaseous phases. In this, the process in the first $3 \mathrm{~h}$ was limited by proper chemical interaction, while its further development was restricted by diffusion.

Some features of phase-formation were described in the studied polycomponent fluorosilicate systems during solid-phase synthesis. The character of intermediate crystalline compounds substantially affected the morphogenetic patterns of fluoramphibole formation by donating specific structural fragments aimed to be bound with growing borders of fluoramphibole crystals. The higher rate of condensation of silicoxygen tetrahedrons enabled the formation of silicates with more complex structure of anion radical.

Examining the morphogenetic patterns, we noticed that the fluoroamphibole in form of fibrous-acicular crystals was formed near the low temperature border of their stability, and 
when the mining rock of monomineral composition serpentinite was used at its high dispersivity. The mineralizing substances allowed modifying the properties of intermediate compounds and the physical-chemical parameters of the initiation of solid-phase interactions, thereby, offering a possibility for purposeful changes in the habits of crystals from prismatic to fibrous. The described course of the solid-phase synthesis from mining rocks as well as the properties and characteristics of obtained fibrous fluorosilicates were typical for the compounds of non-stoichiometric composition. Thus, the non-stoichiometric composition of amphibole enabled its yield from inexpensive and more affordable nonstoichiometric raw material.

In comparison with natural and synthetic hydroxyl amphiboles the fluoramphiboles obtained by solid-phase synthesis from mining rocks decayed at higher $\left(120-180^{\circ} \mathrm{C}\right)$ temperature. By their acid- and alkaline-resistance as well as by their adsorptive properties the synthesized fluorosilicates did not concede to the top-graded natural amphiboles.

\section{Acknowledgment}

This research was funded by grants from Ministry of Finances (92-168) and Ministry of Education and Science (01-392, 98-37, 07-38) of Republic of Armenia to L.Kh.. Dr. Dmitry P. Romanov, Dr. Boris V. Volkonsky, and Dr. Galina I. Kosulina, deserved our special thanks for their help with taking the X-ray diffraction, DTA, and elecronmicroscopic images. Dr. Lidia F. Grigor'eva is sincerely acknowledged for her valuable comments. We are very grateful to our spouses Dr. Benik G. Yeritsyan and Gevorg E. Gevorgyan, who provided the support with the graphical illustrations and were always available for helpful scientific discussion; they sustain us in all we do and it is to them that this work is dedicated with love and respect.

\section{References}

Budnikov, P P. \& Ginstling, A.M. (1971). Reactions in the mixtures of solid substances, Publ. by construction, Moscow.

Butt, Yu. I.; Okorokov, S.D.; Sychev, M.M. \& Timashev, V. V. (1965). Technology of cohesive substances, Advanced School, Moscow.

Chigoreva, O.G. (1967). Synthesis and Investigation of Basic Properities Asbestos-like Fibrous Fluoramphiboles, Extended Annotation of Cand. Sci. Dissertation, Institute of Silicate Chemistry after Grebenshchikov, AS USSR. Leningrad.

Chigoreva, O.G. \& Fedoseev, A.D. (1966). Synthesis and investigations of some properities of fibrous alkali amphiboles. In: Investigations of Natural and Technical Mineraloformation, pp. 169-174, Science, Moscow.

Chigareva, O.G. \& Grigor'eva, L.F. (1970). About receipt artifical fluorasbestos from natural talc. Lectures Academy of Science, USSR, ser. Geology, Vol. 195, No. 5, pp. 1194-1196.

Eitel, W. (1952). Synthesis of fluorsilicates of the mica and amphibole group. In: Proc. Intern. Symp. Reactivity of Soids, Gotheburg. Sweden, pp. 335-347.

Eitel, W.; Hatch, R.A. \& Denny, M.V. (1956). Synthetic mica investigations. II. Role of Fluorides in Mica Batch Reaction. Journal of American Ceramic Society, Vol. 36, No. 1, pp. 341-348.

Ernst, W.G. (1968). Amphiboles. Cristal chemistry phase relations and occurence, New York. 
Espig, H. (1962). Beitrag zur Synthese asbestartiger und einiger anderen Silikate. Silikattechnik, Bd. 13, No 4, ss. 131-136.

Fedoseev, A.D.; Grigor' eva, L.F. \& Chigoreva, O.G. (1966). Die Synthesis faseriger Silikate unter thermischen Bedigungen. Kristall und Techn. Bd., H. 2, ss. 231-236.

Fedoseev, A.D.; Grigor' eva, L.F. \& Krupenikova, Z.V. (1963). Synthesis and investigation of the properities of amphibole asbestos-like fibrous minerals. In: Silicates and oxydes in the high temperatures, pp. 180-190, Science, Moscow.

Fedoseev, A.D.; Grigor'eva, L.F. \& Makarova, T.A. (1966). Fibrous silicates, natural and synthetic asbestos, Science, Moscow-Leningrad.

Fedoseev, A.D.; Grigor'eva, L.F.; Chigareva, O.G. \& Romanov, D.P. (1970). Synthetic fibrous fluoramphiboles and their properties. Amer. Mineralogist, Vol. 55, No. 5-6, pp. 854863.

Fedoseev, A.D.; Grigor' eva, L.F.; Chigareva, O.G.; Romanov, D.P. \& Krupenikova, Z. V. (1972). About cationic isomorphism in the synthetic fibrous fluorosilicates. In: Experimental investigations of mineral-formation in the dry oxyde-silicate systems, pp. 141-146, Science, Moscow.

Gibbs, G.V.; Miller, J.I. \& Shell, H.R. (1962). Synthetic fluor-mangesio-richterite. Amer. Mineralogist. Vol. 47, No. 1-2, pp. 75-82.

Godovikov, A. A. (1973). Introduction to mineralogy, Science, Novosibirsk.

Goncharov, Yu. I. \& Kovalenko, V. S. (1973). Toward a mechanism of formation of amfibolic asbestos. Geochimia, No. 5, pp.782-787.

Grigor' eva, L.F.; Makarova, T.A.; Korytkova, E.N. \& Chigareva, O.G. (1975). Synthetic Amfibolic Asbestos. Science. Leningrad.

Hawkins, J.W. (1971). Asbestos: today, tomorrow, the day after tomorrow. Sampe Journal, Dec/Jan, pp. 17-20.

Hodgson A. A. (1965). Fibrous silicates. W.C.I. lecture series, London, No. 4, 46 p.

Istomin, S.S. (1980). The influence of inorganic sodium compounds on thermal dissociation of sodium fluorsilicate. Journal of Applied Chemistry, AS USSR, Vol. 53. No. 6, pp. 1201-1205.

Khachatryan, L.A. (1969). Asbestos-like synthetic fibrous silicates from Armenian mining rocks. Extended annotation of cand. sci. dissertation, Institute of Silicate Chemistry after Grebenshchikov, AS USSR, Leningrad.

Khachatryan, L.A. (2004). Disperse layered silicates in magnesium silicate rocks. Glass physics and chemistry, Vol. 30, No. 1, pp. 67-72.

Khachatryan L.A. (2007). Fibrous Fluorosilicates from Mining Rocks. Chemical Journal of Armenia, NAS RA, Vol. 60, No. 3, pp. 433-445.

Khachatryan, L.A. \& Yeritsyan, N.B. (2003). Nanosized fibrous silicates from mining rocks of magnesium-silicate composition. Chemical Journal of Armenia, NAS RA, Vol. 56, No. 4, pp. 12-22.

Khachatryan, L.A. \& Yeritsyan, N.B. (2011). Synthesis of layered thin-scaly fluorosilicates from mining rocks. Proceedings of 11th European Symposium of Eurofillers, Drezden, Germany, August, 2011.

Kogarko, I.N. \& Krigman, L.D. (1981). Fluorine in silicate melts and magmas. Science, Moscow

Kogarko, I.N.; Krigman, L.D. \& Sharudilo, N.S. (1968). Experimental studies of the effect of melt alkalinity on the detachment of fluorine into the gaseous phase. Geochemistry, No. 9, pp. 948-954.

Koltermann, M. (1965). Ber. Dtsch. Keram. Ges, Bd. 42, Hf. 10, ss. 373. 
Kuvakin, M.A. (1971). Ternary mutual system of sodium and magnesium fluorides and sodium and magnesium chlorides. Journal of Applied Chemistry, AS USSR, Vol. 16, No. 12, pp. 3290-3292.

Li, K. (1992). Feijinshu Kuang-Nen-Metal. Mines, No. 4, pp. 47-49.

Lüdke, W. (1933). Metrodisches zur Synthese von Silikaten mit leichtfluchtigen Substanzen unter stationären Bedingungen. A. Hornblendesynthesen. Fortschr. Mineral, Bd. 18, ss. 29-31.

Lüdke, W. (1943). Verfabren zur Herstellung von Asbestos mit langeren Fasern aus kürzfaserigen synthetischen Asbestos. Pat. Gemany.1.95221, Ivb (12i) 38.

Nikitin, B.N.; Litvinova, T. I.; Raichenko, T. F. \& Voronov, V.A. (1973). Ternary mutual system from magnesium and silicon fluorides and oxides. Journal of Applied Chemistry, AS USSR, Vol. 46, No. 3, pp. 646-648.

Novoselova, A.V. \& Azhikina, Yu.V. (1966). Investigation of the equilibrum in the system containing beryllium oxide, silicon dioxide, and sodium fluoroberyllate. Reports of AS USSR, Inorganic Materials, Vol. 2, No. 9, pp.1604-1607.

Novoselova, A.V.; Orlova, Yu.V.; Sobolev, B.P. \& Sidorov, L.I. (1964). On the mechaanism of formation of beryllium silicate. Lectures AS USSR, ser. Chemical, Vol. 159, No. 6, pp. 1338-1341.

Prodan, E. A.; Pavlynchenko, M.M. \& Prodan, S.A. (1976). Regularities of Topochemical Reactions, Science and technique, Minsk.

Rabenau A. (Ed.). (1970). Problems of non-stoichiometry, North-Holland Publishing Company, Amsterdam-London.

Ryss, I.G. (1956). The chemistry of fluorine and its inorganic compounds, Goskhimizdat, Moscow.

Saito, H. \& Takusagawa, N. (1965). Synthesis of fluor-manganese-richterite asbestos by sintering method. Journal of Chemical Society of Japan, Ind. Chem. Soc. Vol. 68, No. 12 , pp. $2347-2351$.

Scheumann, K.H. (1932). Über Hornbleendesdesynthesen bei niedrigen Drucken. Fortschr. Mineral, Bd. 17, s. 447.

Sharma R.A. \& Johnson, I. (1969). Journal of American Ceramic Society, Vol. 52, p. 612.

Simons, J. (Ed.). (1950). Fluorine chemistry, Academic, New York.

Spitsyn, V.A.; Shostak, V. I. \& Meerov, M.A (1952). A study of the volatility of alkali metal chlorides at high-temperatures. Journal of General Chemistry, Vol. 22, No. 4, pp. 758766.

Tareev B.M. (2002-2011). Electrotechnological materials. Available from: http:/ /aznku.ru/met-meb/elektromaterial/88/index.html.

Tresvyatskiy, S.G. (Ed.). (1982). New materials from oxides and synthetic fluorosilicates, Naukova dumka, Kiev.

Tret'yakov, Yu. D. (1978). Solid-phase reactions, Chemistry, Moscow.

Wartenberg, H.V. (1953). Z. Anorg. Allgen. Chem, Bd. 273, No 3, ss. 257-268.

Yeritsyan, N.B. \& Khachatryan, L.A. (2005). Synthesis of nanosized fibrous silicates from mining rocks in hydrothermal conditions, Proceedings of 8th European Symposium of Polymer Blends and Eurofillers, Bruges, Belgium, May 9-12, 2005. 


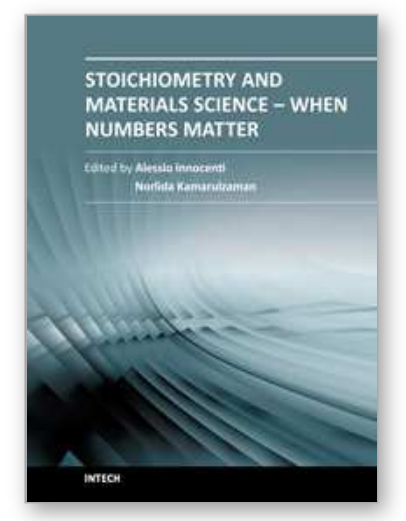

\author{
Stoichiometry and Materials Science - When Numbers Matter \\ Edited by Dr. Alessio Innocenti
}

ISBN 978-953-51-0512-1

Hard cover, 436 pages

Publisher InTech

Published online 11, April, 2012

Published in print edition April, 2012

The aim of this book is to provide an overview on the importance of stoichiometry in the materials science field. It presents a collection of selected research articles and reviews providing up-to-date information related to stoichiometry at various levels. Being materials science an interdisciplinary area, the book has been divided in multiple sections, each for a specific field of applications. The first two sections introduce the role of stoichiometry in nanotechnology and defect chemistry, providing examples of state-of-the-art technologies. Section three and four are focused on intermetallic compounds and metal oxides. Section five describes the importance of stoichiometry in electrochemical applications. In section six new strategies for solid phase synthesis are reported, while a cross sectional approach to the influence of stoichiometry in energy production is the topic of the last section. Though specifically addressed to readers with a background in physical science, I believe this book will be of interest to researchers working in materials science, engineering and technology.

\title{
How to reference
}

In order to correctly reference this scholarly work, feel free to copy and paste the following:

Naira B. Yeritsyan and Lida A. Khachatryan (2012). The Solid-Phase Synthesis of the Inorganic NonStoichiometric Compounds-Fibrous Fluorosilicates, Stoichiometry and Materials Science - When Numbers Matter, Dr. Alessio Innocenti (Ed.), ISBN: 978-953-51-0512-1, InTech, Available from:

http://www.intechopen.com/books/stoichiometry-and-materials-science-when-numbers-matter/the-solidphasesynthesis-of-the-inorganic-non-stoichiometric-compounds-fibrous-fluorosilicates

\section{INTECH}

open science | open minds

\section{InTech Europe}

University Campus STeP Ri

Slavka Krautzeka 83/A

51000 Rijeka, Croatia

Phone: +385 (51) 770447

Fax: +385 (51) 686166

www.intechopen.com

\section{InTech China}

Unit 405, Office Block, Hotel Equatorial Shanghai

No.65, Yan An Road (West), Shanghai, 200040, China

中国上海市延安西路65号上海国际贵都大饭店办公楼405单元

Phone: +86-21-62489820

Fax: $+86-21-62489821$ 
(C) 2012 The Author(s). Licensee IntechOpen. This is an open access article distributed under the terms of the Creative Commons Attribution 3.0 License, which permits unrestricted use, distribution, and reproduction in any medium, provided the original work is properly cited. 